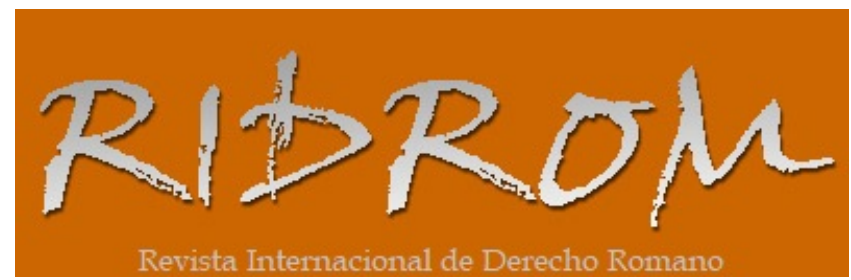

ISSN 1989-1970

Abril-2021

www.ridrom.uclm.es

Full text article

\begin{tabular}{|c|c|}
\hline $\begin{array}{c}\text { Fecha de recepción: } \\
19 / 12 / 2020\end{array}$ & $\begin{array}{c}\text { Fecha de aceptación: } \\
10 / 02 / 2021\end{array}$ \\
\hline $\begin{array}{l}\text { Palabras clave: } \\
\text { Comercio marítimo, Exportación, Mercancias ilícitas, Imperio Absoluto, } \\
\text { Código Teodosiano. }\end{array}$ & $\begin{array}{c}\text { Keywords: } \\
\text { Maritime trade, Exports, Illicit goods, Roman Empire, Codex } \\
\text { Theodosianus. }\end{array}$ \\
\hline
\end{tabular}

\title{
NOTAS RELATIVAS A LAS LIMITACIONES INTRODUCIDAS AL COMERCIO EXTERIOR POR VÍA MARÍTIMA, CONFORME A C. Th. 7, 16, 3. Año 420 D. C.
}

\section{NOTES ON LIMITATIONS IMPOSED ON EXTERNAL TRADE BY SEA, ACCORDING TO THE THEODOSIAN CODE 7, 16, 3. YEAR 420 D. C.}

\author{
Beatriz García Fueyo \\ Universidad de Málaga
}

(GARCÍA FUEYO, Beatriz. Notas relativas a las limitaciones introducidas al comercio exterior por vía marítima, conforme a C.Th.7,16,3. Año 420 D.C.. RIDROM [on line]. 26-2021. ISSN 1989-1970. p. 64-148. http://www.ridrom.uclm.es)

\section{Resumen:}

El año 420 d. C., Teodosio II, consigue que Honorio, acepte un planteamiento global en el Imperio, aunque él era el beneficiado del mismo, y se promulgue C. Th. 7, 16, 3. En esta constitución se prohíbe que un barco salga a transportar mercancías por el Mar Mediterráneo, si previamente el armador o el comerciante no declaran, ante el defensor del lugar y en presencia del oficial más inmediato al general del territorio, el destino al que se dirigen, de lo que se deja constancia en acta, además de no transportar mercancías ilícitas, que no se describen en esta norma, y que la manifestación se realiza sin violencia o extorsión alguna. Esta

prescripción normativa pasa más simplificada al Código de Justiniano, 12, 44 (45), 1. Este deber de manifestación por parte del magister navis o nauclerus, se mantiene vigente en la Baja Edad Media y en la Edad Moderna.

\footnotetext{
Abstract:

In the year $420 \mathrm{~d}$. C., Theodosius II succeded in making Honorius accept a global approach in relation to the Empire, although he was the beneficiary of it, and it is promulgated. C. Th. 7, 16, 3. According to this Constitution, a ship is prohibited from leaving the Port to transport goods through the Mediterranean Sea if the shipowner or the merchant do not declare -before the defender of the place and in the presence of the most immediate officer to the General of the territory- the destination intented for the ship and that they are not illicit goods, which are not described in this rule. Everything is put on record and the statement must

lack violence or extortion. The Justinian Code, 12, 44 (45), 1, mantains this regulation. This duty of manifestation by the magister navis or nauclerus in regard to the destination of the ship, remains in force in the Low Middle Ages and in the Modern Age.
} 
SUMARIO: 1. Introducción. 2. La Constitución imperial de Teodosio y Honorio, C. Th. 7, 16, 3, del año 420. 3. Aspectos terminológicos de la norma. 4. Contexto histórico-político y socioeconómico que explica su emanación. 5. Alcance e interpretación del precepto legislativo. 5. Reinserción parcial de su contenido en el Código de Justiniano 12, 44 (45), 1 y su Recepción en la Baja Edad Media y Edad Moderna. 6. Conclusiones

\section{INTRODUCCIÓN}

Analizamos y reflexionamos en estas páginas sobre un precepto relativo al transporte de mercancías por vía marítima, en relación con la prohibición de comerciar con algunos productos más allá de las fronteras del Imperio, junto al control del tráfico marítimo para exportar bienes del territorio romano, a principios del siglo $\mathrm{V} \mathrm{d}$. C.

Estamos ante una materia que en parte afecta al Derecho mercantil, pero en parte es Derecho administrativo, si nos atenemos a las medidas adoptadas por el poder político imperial para dar respuesta a una situación que el Emperador y sus principales colaboradores entendían de grave riesgo para la supervivencia del Estados ${ }^{1}$.

Es una experiencia histórica, que se reitera actualmente en muchos países, aunque sea temporal, respecto de su comercio con otras naciones, tal como presenciamos desde hace unas décadas por parte de EEUU con Cuba, y más recientemente con Venezuela, que no precisa mayor consideración, porque es bien conocida. Esta

\footnotetext{
${ }^{1}$ Este trabajo se inserta dentro del proyecto investigador que inició en España, hace dos décadas, el profesor Dr. D. Antonio Fernández de Buján, sobre el análisis en diversas ramas del Ordenamiento, como Derecho administrativo, Derecho fiscal o Derecho medioambiental.
} 
materia, en perspectiva histórica, tiene gran utilidad para la formación del jurista moderno, si buscamos que los estudiosos del derecho no sean meros cultivadores del comentario a las leyes emanadas por el poder político, carentes de una perspectiva de futuro, y deseamos que sean capaces de entender la realidad presente desde su conformación histórica.

Recordaban Sandiford y Papi Spanu², que el mar ha sido siempre, desde las épocas más remotas, un campo de actividad humana, y dado ocasión, en la vida de los pueblos, a relaciones de paz y de guerra, que encuentran su regulación en normas fijadas en las leyes propias de cada país, y en convenciones internacionales, además de usos y costumbres, dando lugar a convertirse en un elemento de prosperidad y poder para muchas naciones.

Inicialmente era un medio de encontrar sustento, con el que satisfacer necesidades, pero pronto entró en juego la especulación, basada en la diferencia de precio, entre el costo de los productos de los mercados de origen, y el que paga quien consume. Por este hecho, el transporte a través del agua fue un medio complementario, subsidiario y, en ocasiones, necesario con el transporte terrestre.

Alrededor de la nave se desarrolló una red de intereses, que toma en cuenta no solamente el medio en el que se ejecuta la actividad, sino también la misma actividad a la que dio origen, cuyas implicaciones hicieron que fuese necesario regularla, no solamente porque fue ejercida por personas cualificadas de relevante especialización, sino

2 SANDIFORD, Roberto - PAPI SPANU, Luigi, Istituzioni di Diritto della navigazione, vol. I, rist., Roma, Ateneo, 1948, p. 17 y 34-35. 
porque servía para poner en contacto pueblos diferentes y lejanos, dando lugar a usos y costumbres.

Un sector doctrinal entendió que los antiguos romanos no tuvieron muy presente el tráfico y la navegación, o al menos que no les dieron gran importancia, lo que contrasta con las múltiples disposiciones legislativas que están diseminadas en numerosísimos fragmentos y constituciones del Corpus Iuris Civilis de Justiniano, y en algunos preceptos del Código Teodosiano, sin olvidar la relevancia de la "Lex Rhodia de re nautica", asumida por los romanos, "quatenus nulla lex ex nostris ei contraria est", tal como vemos en el jurisconsulto Volusio Meciano, D. 14, 2, 9, y recoge en el régimen aplicable Pauli Sententiae 2, 7, 1-5.

Las fuentes del derecho marítimo romano se localizan en un centenar de fragmentos del Digesto, trece constituciones del Codex de Justiniano y algunas del Código Teodosiano, ocupándose de institutos relacionados con la industria del transporte, además de lo relativo al dominio público sobre el litoral, el derecho de pesca, la responsabilidad del armador y del exercitor navis, del depositario, sobre hurtos y daños causados a las mercancías embarcadas, e indirectamente al derecho de la navegación marítima.

Entiende Brunetti ${ }^{3}$ que la navegación en Roma alcanzó mucha relevancia en época imperial, mediante barcos a remo y a vela, armados por particulares, generalmente para el transporte de grano (naves annonariae) y de mármoles, probablemente subsidiadas por el Estado, las cuales surcaban el mediterráneo, convertido en un lago

3 BRUNETTI, Antonio, Diritto marítimo privato italiano, vol. I, Torino, Unione Tipografica, 1929, pp. 74-76. 
romano, con desarrollo de su actividad incluso desde el Mar Rojo hasta el Océano Índico, llegando al Atlántico y a los mares septentrionales.

Podemos asumir que la legislación marítima de época imperial está influenciada por la normativa griega, con institutos tales como los de la echazón y el foenus nauticum, aunque los romanos se ocuparon de múltiples instituciones, algunas conexas con la industria del transporte naval. Muchos fragmentos del Digesto de Justiniano abordan materias tales como los recepta, en la acción exercitoria, el depósito, el hurto frente a los nautas, en caso de naufragio, sin olvidar que ocasionalmente hay reglas en otras sedes, como en el arrendamiento ${ }^{4}$.

\section{LA CONSTITUCIÓN IMPERIAL DE C. Th. 7, 16, 3, DE TEODOSIO II Y HONORIO. AÑO 420}

La prohibición general, y totalmente discrecional, por parte del poder político del Imperio Absoluto, a la hora de exportar "merces illicitae ad barbaras nationes", no solamente implica unas limitaciones el comercio internacional, sino que también, y especialmente, articula un sistema de vigilancia y control administrativo, realizado desde el puerto o lugar del litoral que eran el origen de la nave, hasta el último lugar de desembarco de las mercancías transportadas, respecto de

\footnotetext{
4 Vid. Tedeschi, Il diritto marittimo dei romani, Montefiascone 1899; SANDIFORD, Roberto, Il diritto marittimo dei romani, Roma 1941; SOLAZZI, Siro, Appunti di diritto romano marittimo, en Rivista del Diritto della navigazione, 1936, 113 y 268; BIGIAVI, Studi di storia del diritto commerciale romano, en Rivista del Diritto Commerciale, 1930, I, p. 850 y ss.
} 
cualquier barco, para impedir, entre otras cosas, el contrabando con las naciones enemigas, aunque también los emperadores de Oriente y Occidente previeran, y quizás temían más, que el simple intercambio de bienes, que generaba mucha riqueza, se transformara en negocios con gran daño para la seguridad del territorio ${ }^{5}$ :

Idem (Honorius et Theodosius) AA. Eustathio praefecto praetorio. Saluberrima sanctione decrevimus, ne merces illicitae ad nationes barbaras deferantur, et quaecumque naves ex quolibet portu seu litore dimittuntur, nullam concussionem vel damna sustineant, gestis apud defensorem locorum praesente protectore seu duciano, qui dispositus est, sub hac observatione confectis, ut, et ad quas partes navigaturi sunt et quod nullam concussionem pertulerunt, apud acta deponant: quorum authenticum nauclerus sive mercator habebit scheda apud defensorem manente. Dat. XIIII kal. oct. Constantinopoli $d$. n. Theodosio a. VIIII et qui fuerit nuntiatus. (420 sept. 18).

El fragmento de la norma posclásica resulta de gran interés, por las medidas adoptadas, en aras del buen fin propuesto:

Los mismos Augustos (Honorio y Teodosio) a Eustatio prefecto del pretorio. Mandamos por esta muy saludable

\footnotetext{
${ }^{5}$ CTh.7.16.3. 8 de septiembre del año 420. Sobre la obra legislativa y su contenido, vid. ARCHI, Giangualberto, Teodosio II e la sua codificazione, Napoli, Jovene, 1976; DE MARINI AVONZO, Francesca de, La politica legislativa di Valentiniano III e Teodosio II, $2^{\mathrm{a}}$ ed., Torino, Giappichelli, 1975; MATTHEWS, John F., Laying Down the Law. A study of the Theodosian Code, Yale, University Press, 2000; AA. VV., The Theodosiam Code. Studies in the Imperial Law of late Antiquity, ed. By J. Harries et Ian Wood, London, Duckworth, 1993;
} 
disposición, que no se lleven mercancías ilícitas a las naciones extranjeras, y cualquier nave que se envía desde cualquier puerto o litoral, no soporte ninguna concusión o daños, habiendo declarado ante el defensor de los lugares, presente el protector o duciano, que está nombrado para ello, manifestando por escrito, y bajo esta advertencia, a qué lugares habrán de navegar y que no sufrieron concusión: el capitán de la nave o el comerciante tendrá el original de estos documentos, y una cédula queda en manos del defensor. Dada en Constantinopla el 18 de septiembre del año 420.

Señala Clyde Pharr'6, en la traducción e interpretación personal del Código Teodosiano ${ }^{7}$, al analizar esta constitución imperial, que en la misma se decreta que ninguna mercancía ilícita, matizando que bajo tal calificativo se identificaban los bienes fruto de contrabando, esencialmente aquellos usados en tiempos de guerra, conforme a lo dispuesto en la constitución imperial de los mismos emperadores, fechada el 24 de septiembre del año 419, C. Th. 9, 40, 24, deberá ser exportada a las naciones bárbaras; y si algún barco fuera enviado desde un puerto o costa, en los términos de la ley, no sufrirá extorsiones o pérdida, recordando que en aquel tiempo era habitual

6 PHARR, Clyde, in collaboration with Theresa Sherrer Davidson and Mary Broum Pharr, with an introduction by C. Dickerman Williams, The Theodosiam Code and Novels and The Sirmondian Constitutions. A translation with commentary, glossary, and bibliography, Princeton, University press, 1952, pp. 174-175, y nots 910.

7 Vid. COMA FORT, José María: Codex Theodosianus: historia de un texto, Madrid, Universidad Carlos III, 2014. 
el soborno y la extorsión, por parte de oficiales de la milicia o funcionarios del Imperio, radicados en las provincias.

En criterio de Pharr, las disposiciones contenidas en esta Constitución eran claramente inadecuadas para controlar este mal, al que trataba de dar solución, ya que las víctimas de la extorsión se sentían tan intimidadas, que les era imposible testificar contra su opresores, y a esta situación lamentable se refiere la constitución de 26 de abril del año 380, de los emperadores Graciano, Valentiniano y Teodosio I, recogida en C. Th.7, 13, 9.

El soborno indujo a menudo a los habitantes de las provincias a confabularse o asociarse con funcionarios corruptos, pero también en ocasiones este comportamiento era fruto de la intimidación. En este texto legislativo imperial no se indica la naturaleza exacta de la corrupción, es decir, en qué consistía, aunque es posible que se trate de acuerdos colusorios, es decir, acuerdos privados, para limitar, de forma fraudulenta, la competencia jurisdiccional, en caso de reclamación por parte del particular afectado, a fin de proporcionar y asegurar el pago de precios exorbitados, a los funcionarios encargados de esas tareas de vigilancia y control.

Los registros oficiales del tráfico comercial marítimo, a partir de esta ley, se harían ante el defensor del municipio, y en presencia de un oficial próximo al jefe militar, previamente asignado para dicho territorio, ordenando una regulación, a tenor de la cual el nauclerus o el mercator debían dejar constancia, en dichos registros, a qué lugares se dirigían, así como declarar que no habían sufrido ninguna extorsión. El capitán del barco o el comerciante mantendrían en su 
poder el original de estos registros, y una copia quedaría en la oficina del defensor del municipio.

\section{TERMINOLOGÍA MÁS RELEVANTE DE LA CONSTITUCIÓN IMPERIAL}

En la redacción del texto contenido en el Teodosiano, encontramos varios términos que resultan de interés en cuanto a su significado, aunque algunos de ellos son equívocos, de modo que es difícil precisar el que asumen concretamente en este precepto. Entre otros, debemos citar los de nauclerus, ducianus, protector, defensor civitatis, concussio, etc. ${ }^{8}$.

Aparte de los Diccionarios latinos, en los que puede observarse la diversidad de significados que atribuyen a los términos más relevantes de la norma teodosiana9 ${ }^{9}$ el vocablo cuya significación ha

\footnotetext{
${ }^{8}$ Gradenwitz puso de relieve la reiteración o singularidad de algunos de los que merecen ser tomados en cuenta, y los lugares concretos referidos en el Codex Theodosianus: GRADENWITZ, Otro, Heidelberger Index zum Theodosianus, mit Ergänzungsband. Hergestellt unter Leitung von..., Weidmann 1970: p. 137; mercator, 7, 16, 3 año 420; p. 68: s. v. ducianus: 7, 4, 30, año 409; 7, 16, 3, año 420; 11, 25, 1, año 393; 15, 11, 2, año 417; p. 57, s. v. defensor, abundantes referencias; p. 28, s. v. authenticus, 7, 4, 11, año 364; 7, 4, 13 del 365; 7, 4, 16, del año 370; 7, 16, 3 del año 420; p. 192, s. v. protector, con abundantes referencias; p. 144, s. v. nauclerus: 7, 16, 3, año 420; 13, 5, 32, año 409; 14, 26, 1, año 412; p. 223, s. v. scheda: solamente aparece en 7, 16, 3, año 420; p. 103, s. v. illicitus, incluye muchos fragmentos, entre ellos el 7, 16, 3, en cambio no aparece en la voz merces, que debería figurar en p. 137; p. 41, s. v. concussio: 1, 15, 7, del año 331; 6, 20, 8, del año 395; 7, 16, 3, del año 420; 8, 10: rubrica; 22, 7, 1, del año 315; 11, 7, 20, del año 412; 11, 20, 4, del año 423; 12, 6, 22, del año 386; 13, 5, 9, del año 357; 14, 16, 3, del año 434.

9 DE MIGUEL, Raimundo, Nuevo Diccionario latino-español etimológico, Madrid, Sáenz de Jubera, 1931, p. 599, s. v. nauclerus; Ibid., p. 311, s. v. ducianus; ilbid., p. 758: s. v. protector; ibid., p. 569, s. v. mercator:; ibid., p. 103, s. v. authenticum; ibid., p. 836, s. v. scheda. ERNOUT, A. - MEILLET, A., Dictionnaire étymologique de la Langue Latine. Histoire des mots, $4^{\mathrm{a}}$ ed., $2^{\mathrm{a}}$ tir., augm. de corr.
} 
generado mayor disensión en la doctrina, y en los historiadores, en su cometido dentro del pueblo romano, así como en la equivalencia con una terminología moderna, es el de nauclerus, que algunos identifican con navicularius ${ }^{10}$.

Cuyacio"11, no duda en sostener paladinamente: "navicularii, naucleri, navarchi, nautici, exercitores navium idem sunt", para añadir algunas matizaciones: "Diversi sunt magistri... id est gubernatores... diversi nautae ${ }^{12}$, qui navis navigandae causa in navi sunt: aliquando tamen nautae pro naucleris accipiuntur". Este humanista, comentando el libro sexto del Código Teodosiano ${ }^{13}$, entiende que los navicularii residen en la Urbe-Roma, desde donde contratan el abastecimiento de la annona, transmitiendo su situación a los herederos, de modo que si alguno

nouv., París, C. Klincksieck, 1967, p. 601-602, s. v. scida = scheda, cédula. CONTE, Gian Biagio - PIANEZZOLA, Emilio - RANUCCI, Giuliano, Il dizionario della Lingua latina, Firenze, Le Monnier, 1994, p. 122, s. v. authenticus (a, um); ibid., p. 342, s. v. Ducianus; ibid., p. 991, s. v. protector; ibid., p. 778, s. v. Nauclerus; ibid., p. 739 , s. v. mercator.

10 Sirva como referencia la postura adoptada por el romanista italiano De Martino, que no se pronuncia a favor de ninguno de los significados que aporta. DE MARTINO, Francesco, Historia económica de la Roma antigua, trad. del ital. por E. Benítez, vol. I, Torrejón de Ardoz, Akal, 1985, p. 433: sobre el significado de navicularii hay diversas interpretaciones: unos afirman que es igual a magister navis y poseedores de naves, otros a curatores navium, y otros a armadores.

11 CUJAS, Jacques, Ad librum XI Codicis Dom. Iustiniani commentarii, en Operum, t. II, Neapoli, typ. Moriana, apud V. Pauria, 1758, cols. 788-789:

${ }_{12}$ GUARINO, Antonio, Diritto privato romano, $4^{\mathrm{a}} \mathrm{ed}$. riv., Napoli, Jovene, 1970, pp. 1003, sobre el receptum nautarum y nota 103.6 la bibliografía, y 1070, sobre la responsabilidad del nauta.

13 CUYACIO, Jacques, Ad titulum LXII de heredibus decurionum, libro VI Codicis, en Operum, t. IX, Neapoli, typ. Moriana, apud V. Pauria, 1758, col. 906: "navicularii hi sunt in urbe, qui annonae urbis serviunt invehendae, quorum est certum corpus, certaque conditio, quae obstringit etiam eorum successores et bona et pro isto munere, quod Reipublicae impendunt, multa privilegia corpus naviculariorum habet, quae proponuntur in titulo de naviculariis infra libro 11, et inter cetera, ut uno ex eis mortuo nullo herede relicto, hereditas ejus non veniat ad fiscum, sed ad corpus naviculariorum, quod idem etiam constituit Valentinianus in Novella de naviculariis: item ex lege 2 hoc titulo". 
fallece sin tener sucesor, no pasan sus bienes al fisco, sino al corpus o colegio de los navicularii, ya que disfruta de una condición personal, que se transmite juntamente con la adscripción del patrimonio.

Peck $^{14}$, entiende que navicularii, siguiendo al humanista Budeo, son los dueños de las naves, a los que se denominan en griego naucleri. Si disponen de naves de cierta entidad, reciben el nombre de patronos. Asimismo, recuerda que a los que van al frente de una nave de una flota se les nomina en griego navarchos y, en terminología del vulgo, capitán o jefe de una armada marina. Entre los productos de utilidad pública que se les confían, incluye "proprie, qui annonam vel aromata ad rem publicam pertinentia praefectorum iussu in alias transvehunt regiones, sed hoc loco omnes intelligi velim, qui quidvis ad rempublicam pertinens, Principis iussu trans mare vehunt, sive in exercitum annonam ferendam suscipiant, sive arma, sive Ducis iussu, non autem alias". El transporte, incluido el marítimo, debía gozar de absoluta seguridad, concretando su contenido: "ista securitas consistit: nec arrestari, nec detineri, nec ad vectigalium solutionem compelli possunt", puesto que tienen el privilegio de exención de impuestos, aunque si el poder político necesita las naves privadas, el dueño de las mismas está obligado a proporcionarlas para utilidad pública ${ }^{15}$.

14 PECK, Pierre, In omnes titulos ad rem Nauticam pertinentes, Hagae-Comitis, ex off. Hildebrandi Iacobi, 1603, pp. 269-270, comentando la ley 1, libro XI, del Código de Justiniano, tit. De naviculariis sive naucleris publicas species transportantibus.

15 Reproduce literalmente el fragmento D. 14, 1, 1, 15. Ulp. libro 28 ad ed. Vid. PECK, Pierre, In omnes titulos ad rem nauticam pertinentes..., op. cit., p. 7. 
En el Daremberg-Saglio ${ }^{16}$ se identifica nauclerus con patrón, propietario o armador de la nave, Besnier, en el mismo diccionario y voz navicularius ${ }^{17}$, diferencia entre el mundo griego y el de Roma, asignándole al naukleros, en el período helenístico, un triple significado, aunque el más frecuente lo identifica con el armador ${ }^{18}$. Si este no realiza las funciones de capitán, y no viaja con la nave, se hace reemplazar por un vigilante, sin dejar de observar que la grafía latina fue la de nauclerus, la cual cayó pronto en desuso ${ }^{19}$.

Huvelin, al tratar del personal de la nave ${ }^{20}$, destaca, en primer lugar, al armador o exercitor, que podía ser propietario, usufructuario o arrendatario, por más o menos tiempo, pero que disfruta de un barco y percibe sus rendimientos. No obstante, pone de relieve que el armador debe diferenciarse del dominus navis, o propietario de la nave, conforme a D. 27, 1, 17, 6, pues armador es la persona que dota al navío del personal y del material necesario para navegar. Se llama patrón o capitán, magister navis, al que pone el armador para la

\footnotetext{
16 Dictionnaire des Antiquités grecques et romaines, D-S, t. IV. Première pàrtie, N-Q, París, Hachette, 1907, reimpr. fot, Graz 1969, p. 3: s. v. nauclerus.

17 BESNIER, Maurice, en Dictionnaire des Antiquités grecques et romaines, D-S, t. IV. Première pàrtie..., op. cit., pp. 20-24: s. v. navicularius.

18 1. El propietario de una nave, que la arrienda a un armador, es decir a un empresario, que se encarga de todo lo que precisa para la navegación, y organiza ésta eligiendo al capitán. 2. El armador de un navío, que puede ser su propietario, o quien solamente lo arrienda, como arrendatario. Su oficio consiste en transportar mercancías. 3. El capitán, puesto por el armador al frente para la administración y dirección de la nave.

19 BESNIER, Maurice, en Dictionnaire des Antiquités..., op. cit., p. 21. La acepción más general en el mundo romano, designa a los empresarios de transportes que realizan el comercio por vía marítima o fluvial, los propietarios de navíos y barcos. Tuvo como sinónimos las expresiones domini navium, de D. 19, 2, 13, 1 y 27, 1, 17, 6, así como el de exercitores navium, según citas de Cicerón y Tácito.

20 HUVELIN, Paul, Estudes du Droit comercial romain (Histoire externe - Droit maritime), París, Sirey, 1929, p. 89.
} 
dirección de la nave. No obstante, a veces nombra otras personas para repartir funciones, o bien las deja indivisas, para que trabajen en común, tal como aparece en D. 14, 1, 1, 13. El patrón tiene bajo sus órdenes una tripulación de diversas especialidades, bien destinadas a la dirección, como el gubernator, bien a la maniobra del barco, a saber, remeros, mesonautas, etc.

Llama la atención del romanista francés 21 , que "les jurisconsultes romains emploient aussi un autre terme qui manque de précision: c'est navicularius ou nauclerus. Il désigne tantôt l'armateur et tantôt le patrón", reconociendo que en los textos jurídicos y epigráficos, navicularius equivale en ocasiones a nauta 22 .

Jones $^{23}$ identifica a los navicularii con los propietarios de naves, entendiendo que los transportes por mar eran función de corporaciones de expedicionarios marítimos (corpora naviculariorum), sujetas a la autoridad de los prefectos del pretorio o de los prefectos

${ }^{21}$ HUVELIN, Paul, Estudes du Droit comercial romain...,op. cit., pp. 89-90.

$22 \mathrm{Si} \mathrm{el} \mathrm{propietario} \mathrm{de} \mathrm{la} \mathrm{nave} \mathrm{es} \mathrm{al} \mathrm{mismo} \mathrm{tiempo} \mathrm{comerciante,} \mathrm{se} \mathrm{sirve} \mathrm{de} \mathrm{su} \mathrm{navío}$ exclusivamente para transportar sus mercancías. No obstante, de ordinario arrienda el navío, sin equipar, y en ese caso hace una locatio rei ordinaria. Si el propietario es también el armador, y arrienda el navío a un tercero, hace un contrato de arrendamiento más complejo, porque junto al arrendamiento de cosa, hay un arrendamiento de servicios, relativos al capitán y otras personas de la tripulación. El armador, propietario o arrendatario puede explotar su navío, conviniendo con una o varias personas a transportar sus mercancías o a las mismas personas, mediante un flete determinado: se trata de un contrato de transporte marítimo. En Roma era una locatio operis faciendi, de modo que el propietario de las mercancías era el locator y el transportista el condjuctor. El contrato no exigía formalidad alguna, y se realizaba entre el patrón o magister navis, actuando como mandatario del armador, y el dueño de las mercancías. Por las obligaciones derivadas del contrato, el armador puede ser demandado con la actio exercitoria.

23 JONES, A. Hugo M. Il tardo impero romano, 284-602 d. C., op. cit., t. III, 1981, pp. 1262-1265 y 1638-1643. 
de la annona de África y Alejandria, los cuales eran responsables ante los prefectos del pretorio de Italia y de Oriente, respectivamente.

También se pronuncia en el mismo sentido Benvenuto Stracca ${ }^{24}$, para quien el navicularius es el propietario de las naves, y equivale al griego naucleros, al que también se calificaba como patrón, si bien en la nomenclatura usual se designaba con el término navicularius al que construía las naves, así como al que se dedicaba al comercio con la nave, y también al que conducía la nave, remitiéndose al criterio manifestado por el glosador Accursio.

El estudioso del Derecho ático, Ugo Paoli25, entiende que el naucleros es el que tiene el mando de una nave, de la que se sirve como medio de crédito para ejercitar el comercio en nombre propio. Las obligaciones que asume no afectan a las cualidades técnicas que se le exigen para ello, ni limitan su actividad comercial, porque ante todo es un comerciante. Para obtener capital, que necesita para realizar actos de comercio mediante cambios transmarinos de mercancía, recurre a la fórmula muy difundida del préstamo marítimo, que en Grecia es atestiguado solo en forma voluntaria: estipula del mutuante, con un fuerte interés en la convención, que el riesgo sea a cargo del que lo entrega, dando como garantía la nave. El naucleros puede ser hombre libre o esclavo, pero tiene derecho a contratar, y responde de esas obligaciones en juicio, que es el cometido de gestión

24 STRACCA, Benvenuto, Tractatus de mercatura seu mercatore... accessit nunc primum eiusdem auctoris quotidianus de Adiecto Tractatus, in quo etiam dotium stipulationes usitatae, et quaestiones quotidianae quidem plene explicantur. Ex quibus tractatus de Mercatura perfectus redditur..., Coloniae Agrippinae, apud Ioannem Gymnicum, sub Monocerote, 1576, p. 240.

25 PAOLI, Ugo Enrico, en Nuovo Digesto Italiano, vol. 8, Torino, Unione tipográfico-editrice, 1939, s. v. naucleros, p. 865. 
asumido por el magister navis en época imperial ${ }^{26}$, quien actúa una forma de representación verdadera y propia, pero de pura sustitución o interposición de gestión. Se obliga en interés propio, y contra él se ejercita la actio exercitoria. Moschetti ${ }^{27}$ comienza por clarificar las figuras del gubernator navis y del magister navis, ya que el primero dirigía las operaciones necesarias para la navegación durante el transcurso de esta hasta la entrada en el puerto de destino, mientras que el segundo se ocupaba de la organización de la vida e intereses comerciales de la nave, ya preparada para llevar a cabo un viaje marítimo. Entre los sujetos, que se dedicaban a la explotación del navío ${ }^{28}$, el naucleros ocupaba el primer lugar, aunque no es el propietario del navío, ni en sentido técnico el armador, ni tampoco el capitán de la nave, como responsable de la navegación, sino representante del propietario o del armador de la nave, encargado de las operaciones comerciales con los consignatarios que han cargado sus mercancías a bordo del barco. Esencialmente era un comerciante, que se servía de la nave como medio de crédito en toda relación comercial, pudiendo actuar en nombre propio, o por cuenta ajena de un dominus, con lo cual también pudo ser libre o esclavo, ya que en las relaciones comerciales el esclavo está equiparado al libre: por ello, frente a los terceros actúa como si fuese propietario de la nave, incluso

${ }^{26}$ Cf. DE DOMINICIS, Antonio, en Nuovo Digesto Italiano, vol. 8, Torino, Unione tipográfico-editrice, 1939, p. 1, s. v. magister navis; BONFANTE, Pietro, Istituzioni di Diritto romano, $8^{a}$ ed., Milano, Francesco Vallardi, 1925, pp. 394-396..

27 MOSCHETTI, Cesare Maria, Notae al libro de J. Rougé, Aspetti organizzativi dell'attività commerciale marittima nel bacino del Mediterraneo durante l'Impero romano, en SDHI 35 (1969) 388.

28 MOSCHETTI, Cesare Maria, Notae al libro de J. Rougé, Aspetti organizzativi dell'attività commerciale marittima..., op. cit., pp. 389-390. 
si no es el propietario, ni el esclavo podía jurídicamente serlo. De sus obligaciones respondía la nave y las mercancías, que usualmente se ofrecían como garantía del pago. El navicularius ${ }^{29}$ es un empresario de transportes marítimos al servicio de la annona, y miembro de una corporación obligatoria y hereditaria; por el contrario, el nauclerus, era un empresario marítimo, que quedó independiente del servicio annonario y, por consecuencia, no sujeto al sistema corporativo, En este período el nauclerus es sinónimo a magister navis, puesto que percibe el precio del pasaje, y se embarca en la nave, a diferencia del navicularius; normalmente es personaje dependiente, aunque está en relación inmediata con los pasajeros.

Según Moschetti ${ }^{30}$, el nombramiento del gubernator navis venía, o del dominus navis o, si este había arrendado el uso de la nave a otro, del exercitor: D. 14, 1, 1, 15. Ulpiano 28 ad ed. El dominus, o en su caso el exercitor navis, fijaba el puerto de salida, la ruta que debía seguir e incluso, a veces, el día de llegada. El gubernator entraba en su oficio bien por designación directa del dueño o exercitor, o bien porque concurría al bando o anuncio público del dueño o exercitor para que apareciese un gubernator y se enrolase en un determinacdo viaje marítimo. Quien respondía a los requisitos del bando, debía demostrar que sabía guiar la nave, y conocer los lugares marítimos en los que debía atracar, prometiendo al término navem in portum perducere; asumía este empeño con valor de obligación: utilem operam

29 MOSCHETTI, Cesare Maria, Notae al libro de J. Rougé, Aspetti organizzativi dell'attività commerciale marittima..., op. cit., p. 392.

30 MOSCHETTI, Cesare Maria, Gubernare navem. Gubernare rem publicam. Contributo alla storia del diritto marittimo e del diritto pubblico romano, Milano, Griuffrè, 1966, p. 48-50. 
et navis regendae scientiam, porque debía llevar salva o indemne la nave, es decir, íntegra, al puerto que le habían indicado. El gubernator se responsabiliza de los problemas derivados del mar durante la navegación, mientras el magister tiene funciones dirigidas a regular las relaciones comerciales marítimas, con un contenido exclusivamente económico, como era el exigir los créditos inherentes a la empresa marítima, pero no lo relativo a la dirección técnica de la nave ${ }^{31}$.

El francés Rougé32, tratando del nauclerus, comienza por reconocer que ya existe en época republicana y fue tomado del griego. Era el personaje con el que los pasajeros tratan de su pasaje, mientras el navicularius asumía funciones comerciales. En el Digesto se define al magister navis como el sujeto al que se confía el cuidado del navío, pero no el de la navegación, según D. 14, 1, 1, 1, ya que esta tarea corresponde al gubernator navis. El magister navis, según el Digesto, depende del armador del barco que le ha otorgado la dirección de la explotación del navío, de modo que no puede ir contra este encargo, de manera que, por ejemplo, si ha dispuesto que solamente se transporten pasajeros, el magister no puede introducir carga de mercancías. El magister navis es el intermediario normal entre el navío

\footnotetext{
${ }^{31}$ Las operaciones económicas y comerciales estaban a cargo del magister navis, mientras las operaciones necesarias para la navegación durante el curso de la misma hasta la entrada en el puerto de destino, quedaban bajo la guía exclusiva y responsabilidad completa del gubernator navis. Por sus conocimientos técnicos y prácticos era la única persona competente para conducir la nave y dirigir la ruta, con diligentia, prudentia, peritia y scientia. Estaba subordinado al magister. MOSCHETTI, Cesare Maria, Gubernare navem..., op. cit., pp. 98-100.

32 ROUGÉ, Jean, Recherches sur l'organisation du commerce maritime en Méditerrenée sous l'Empire Romain, París, SEVPEN, 1966, pp. 233-245.
} 
y los que utilizan sus servicios: pasajeros y cargadores, por lo que tiene una función meramente económica.

El nauclerus ${ }^{33}$, desde su punto de vista, es siempre un personaje embarcado y, en principio, un personaje dependiente: es el que tiene la relación con los pasajeros, quien percibe el precio del pasaje, el naulum. Se encarga del transporte de las cajas o paquetes y de las cartas de expedición, paga a los miembros de la tripulación, y señala las etapas del recorrido. Este nauclerus, atendiendo a sus funciones, no se distingue en nada del magister navis. Entre ellos habría una identidad total ${ }^{34}$.

En el siglo V d. C. se produjo una evolución importante ${ }^{35}$, tanto en Oriente como en Occidente. Siguieron conservándose los términos naucleri y navicularii, pero mientras los primeros corresponden a la función antes citada, son los sujetos que, a bordo de los navíos, responden del cargamento, dirigen la venta de los productos embarcados, y rinden cuentas al Estado, si es un cargamento fiscal, los navicularii no tienen nada que ver con la navegación, y son meros empresarios del transporte.

33 ROUGÉ, Jean, Recherches sur l'organisation du commerce maritime en Méditerrenée..., op. cit., pp. 240-244.

$34 \mathrm{El}$ término nauclerus no aparece en el Digesto, pero se cita en tres fragmentos del Código de Teodosio: en C. Th. 14, 26, 1, relativa al transporte de trigo a Alejandría, del 28 de enero del año 412; C. Th. 7, 16, 3 que se refiere al control de las mercancías prohibidas. También aparece nauclerus en la ley del año 419, C. Th. 13, 5, 32, en la que se ordena la expropiación forzosa de barcos en el Mediterráneo oriental después de una penuria de avituallamiento en Constantinopla, penuria debida a una crisis en el transporte marítimo.

35 ROUGÉ, Jean, Recherches sur l'organisation du commerce maritime en Méditerrenée..., op. cit., pp. 255-258. 
Por lo que se refiere al ducianus de la constitución imperial, Jacobo Godofredo ${ }^{36}$ lo identificó como un oficial de uno de los duces, encargado de esa frontera: "ducianus est ducis limitis alicuius officialis", sin mayor precisión, mientras que los protectores eran militares designados ocasionalmente para guarda de las poblaciones, siguiendo el significado que le asigna C. Iust. $12,38,17 \mathrm{pr}$, en el título relativo a la distribución de la annona militar.

Este humanista del siglo XVI, comentando las constituciones del Teodosiano, pone de manifiesto ${ }^{37}$ que los soldados se oponen a los particulares $u$ hombres privados, quienes por lo mismo están dotados de armas para cumplir sus funciones, mientras que estaba prohibido su uso de ordinario a los particulares, y añade: "Nam in comitatu seu aula imperatorum inque militia palatina, erant armati quidam, veluti domestici et protectores", bajo mandato del magister militum. Godofredo expone sucintamente ${ }^{38}$ que bajo este último, existían unos subordinados que gozaban de mando sobre las tropas, y a los que estaba confiado el cuidado de la milicia, "quorum peculiaris ratio et gradus fuit duces... qui plenius duces militum vocantur: duces limitum... duces provinciarum, quibus et administratio tribuitur", tal como se citan, en el Código de Teodosio II, los duces en Egipto, Armenia, Dacia Ripensis, Libia, Mesopotamia, y Cerdeña, entre otros, así como en los límites del Éufrates y los de Trípoli, de manera que “ab his vero munus

\footnotetext{
36 Codex Theodosianus, cum perpetuis commentariis Jacobi Gothofredi, praemittuntur chronologia accuratior, cum chronico historico et prolegomena, t. II, Lugduni, sumpt. Ioannis-A. Huguetan et Marci-A. Ravaud, 1665, p. 400.

37 Codex Theodosianus, cum perpetuis commentariis Jacobi Gothofredi..., op. cit., p. 252.

38 Codex Theodosianus, cum perpetuis commentariis Jacobi Gothofredi..., op. cit., pp. 255-256.
} 
ipsum dicitur ducatus, et officium eorum, ducianum", añadiendo Godofredo: "Ut et ipsi duciani", con remisión a C. Th. 7, 16, 3.

Jones ${ }^{39}$, por su parte, recuerda que el $d u x$ como jefe militar, incluso con atribuciones superiores al ámbito del gobernador provincial, aparece ya en Diocleciano y en muchas regiones. Con Teodosio II, el magister peditum era el jefe de toda la infantería del ejército de campaña, cualquiera que fuera la provincia en la que estuviera estacionado, mientras el magister equitum lo era de todas las unidades de caballería, y bajo su mando encontramos a los comites rei militaris responsables de los grupos regionales del ejército en campaña y todos los duces de las tropas de frontera. Estilicón, que perdió el poder de modo imprevisto el año 408, reunió en su persona los dos magistri, intitulándose magister utriusque militiae.

Destaca este investigador ${ }^{40}$, que en el ámbito militar, el control de nombramientos estaba muy centralizado, porque era una regla general que todos los que dependían de los altos y medios magistrados, hasta los vicariani, duciani y thesaurenses recibían las probatoriae de los sacra scrinia, y una ley disponía que no solamente los encargos iniciales, sino incluso las promociones estaban sujetas al control del gobierno central ${ }^{41}$. Entre los funcionarios militares, los duciani, al menos en el siglo $\mathrm{V}$, disfrutaban de los mismos privilegios

\footnotetext{
${ }^{39}$ JONES, A. Hugo M. Il tardo impero romano, 284-602 d. C., t. I, trad. de E. Petretti, Milano, Il Saggiatore, 1973, pp. 69-70 y 226.

40 JONES, A. Hugo M. Il tardo impero romano, 284-602 d. C...., op. cit., p. 491.

41 El reclutamiento del ejército no estuvo tan centralizado, hasta que Zenón dispuso que las probatoriae de los soldados, que hasta entonces por costumbre eran emitidas por los magistri militum y por los duces, solamente fueran otorgadas por su persona.
} 
que los limitanei, o militares que custodiaban las fronteras ${ }^{42}$. Los subalternos más inmediatos de los magistri militum eran personas bastante importantes, como demuestra que los duciani ${ }^{43}$ eran personas de cierta relevancia, los cuales, en algunas provjncias, se retiraban con el rango de protector.

Si nos fijamos, finalmente, en el vocabulario de Pharr ${ }^{44}$, ducianus es un comandante militar inmediatamente subordinado al magister militum, jefe supremo del ejército. Tenía el rango de conde, y a menudo se le llamaba conde, en lugar de "conde y duque". Generalmente, estaba a cargo de tropas fronterizas, y era el responsable del distrito miliar en el que estuviera destinado o acampado.

El defensor locorum ${ }^{45}$, también identificado como defensor civitatis $^{46}$, era el defensor del municipio, a saber, un cargo municipal instituído para la protección de las clases sociales bajas contra los más poderosos, en especial frente a los gobernadores de provincias, $\mathrm{y}$ grandes terratenientes. Tenía poderes financieros, judiciales y de policía, además de ser un funcionario relevante del municipio. En

42 JONES, A. Hugo M. Il tardo impero romano, 284-602 d. C...., op. cit., p. 706. Los duces tenían officia similares a los de los gobernadores provinciales, pero sin cornicularius. Los officia de los duces eran muy pequeños, y se elevaba de ordinario a 40. Ibid., pp. 792 y 827.

43 JONES, A. Hugo M. Il tardo impero romano, 284-602 d. C., op. cit., t. II, año 1974, pp. 828-829.

44 PHARR, Clyde, in collaboration with Theresa Sherrer Davidson and Mary Broum Pharr, with an introduction by C. Diskerman Williams, The Theodosiam Code..., op. cit., p. 580.

45 Cf. SANTI ROMANO, en Nuovo Digesto Italiano, vol. 4, Torino, Unione tipográfico-editrice, 1938, pp. 624.627, s. v. Defensor civitatis.

46 PHARR, Clyde, in collaboration with Theresa Sherrer Davidson and Mary Broum Pharr, with an introduction by C. Diskerman Williams, The Theodosiam Code..., op. cit., p. 579. 
ocasiones recibía el nombre de "defensor de la plebe". Sin embargo, acabó deteriorándose su figura y cometidos, convirtiéndose en un individuo corrupto y débil, hasta el extremo que acabó siendo una carga adicional, impuesta sobre los reticentes decuriones.

Explicaba Cuyacio ${ }^{47}$, que en Roma hubo senado, cónsules, tribunos de la plebe, etc., y en otras ciudades del Imperio, por simetría analógica, encontramos la curia, los duunviros y los defensores de la plebe, que inicialmente se nombraban por cinco años, y en la Novela 15, cap. 2, de Justiniano, era un cargo bienal, enumerando sus competencias.

Recuerda Jones ${ }^{48}$ que, a finales del siglo IV d. C., la curia local dejó de ser representativa de la ciudad, y sus funciones fueron transferidas a un nuevo órgano colegiado, comprendiendo al obispo, al clero, y a los principales vecinos del lugar, a los cuales en ocasiones se unen los decuriones. El nombramiento del defensor civitatis fue transferido a este nuevo poder, para la parte Occidental del Imperio, como pronto en el año 409, si bien para el Oriente, el emperador Anastasio procedió de modo similar, un siglo más tarde, el año 505.

La verdadera reforma de la justicia municipal en el Bajo Imperio, en criterio del estudioso citado ${ }^{49}$, se produce con el defensor en cada ciudad. Originalmente era nombrado por el emperador y formalmente se mantuvo este sistema, pero en la práctica a partir del

47 CUYACIO, Jacques, Expositio Novellae XV. De defensoribus civitatum, en Operum, t. II, Neapoli, typ. Moriana, apud V. Pauria, 1758, cols. 1054-1055.

48 JONES, A. H. M., The Roman Economy. Studies in Ancient Economic and Administrative History, ed. por P. A. Brunt, Oxford, B. Blackwell, 1974, pp. 18-19. 49 JONES, A. H. M., The Roman Economy. Studies in Ancient Economic and Administrative History..., op. cit., p. 21. 
último tercio de la cuarta centuria se producía previamente la recomendación de la comunidad, recuperando de este modo la jurisdicción civil de poca entidad o menor sobre sus habitantes.

Valentiniano se preocupó de las clases más humildes, especialmente mediante la figura del oficio de defensor civitatis ${ }^{50}$, aunque las primeras referencias a la figura aparecen en el primer tercio del siglo IV d. C. Las funciones del defensor están definidas en términos generales: es patrono de la plebe contra las injusticias de los poderosos. Decidía casos poco importantes de deudas o restitución de esclavos fugitivos, reclamaciones por exceso en el pago de impuestos, y remitía los casos más importantes al gobernador, asegurando la justicia a los ciudadanos sin gastos excesivos. La institución probablemente no dio los resultados previstos por su fundador, pero permitió el funcionamiento de una justicia accesible y a bajo costo para los ciudadanos pobres, los cuales, en otro caso, habrían debido llevar sus acusaciones ante el gobernador provincial.

Carlos Varela ${ }^{51}$, insiste en la idea fundamental sobre las funciones originarias del cargo, referidas al campo judicial, para evitar la corrupción de los jueces, en perjuicio de los más débiles, con competencia en la pequeña jurisdicción civil y penal; también en el ámbito de los impuestos, para evitar la inicua distribución de cargas fiscales. Posteriormente tuvo la protección de los poseedores de tierras, contra la rapacidad de los agentes del fisco. Se encargó de la administración de los registros públicos, acta o gesta, donde los

50 JONES, A. Hugo M. Il tardo impero romano, 284-602 d. C., op. cit., t. I, pp. 191192.

51 VARELA GIL, Carlos, El estatuto jurídico del empleado público en Derecho romano, Madrid, Dykinson, 2007, pp. 193-195. 
ciudadanos dejaban constancia de las injusticias que sufrieran; prevenían robos, perseguían a los ladrones, y remitían al órgano jurisdiccional competente a quienes, sorprendidos en flagrante delito de robo, homicidio, estupro, rapto o adulterio, fueran entregados al defensor, mediante acta pública ${ }^{52}$.

Advertía Cuq ${ }^{53}$, que la opresión de la plebe, que habitaba en las aldeas, y especialmente en la campiña, es un hecho que testimonian numerosas constituciones. La ausencia de control favorecía los abusos de los funcionarios, desde el prefecto del pretorio hasta el más modesto empleado de los magistrados provinciales. Los curiales, incluso, para liberarse de sus cargas, se convierten en tiranos de sus conciudadanos. Los emperadores juzgaron necesario establecer un defensor civitatis, encargado de proteger a la plebe contra los abusos de los que era víctima. Se afirmaba que la fecha de creación de esta figura fue el año 364, C. Th. 1, 29, 1, pero más recientemente se sostiene que ya existía en el año 336, e incluso probablemente en el año 319. Respecto de su jurisdicción en el Bajo Imperio ${ }^{54}$, subordinados a los gobernadores y a los magistrados municipales, estaba limitada a las minores causae, de valor hasta 50 sólidos, y más tarde hasta 300 sueldos de oro, C. Iust. 1, 55, 1, y Novela 15, capítulos 2 y 4 . Este defensor civitatis rápidamente se expandió, de modo que el

\footnotetext{
52 Este autor entiende que sus cometidos se parecen mucho a los de un moderno comisario de policía.

53 CUQ, Edouard, Manuel des Institutions juridiques des Romains, París, Librairie Plon, 1917, p. 8.

54 CUQ, Edouard, Manuel des Institutions juridiques des Romains..., op. cit., p. 815.
} 
año 385 había defensores civitatis o locorum en todas las provincias: C. Iust. $1,55,455$.

En opinión de Humbert56, concussio designaba en Derecho romano un crimen especial, consistente en la extorsión que se realizaba a un sujeto por parte de un particular o de un funcionario público, a causa del "terreur, des valeurs quelconques, en l'effrayant au moyen de manoeuvres illicites, tendant a lui faire croire à l'existence chez l'agent" de un derecho o poder imaginario, o abusando de un poder real. Confundido muchas veces con el crimen repetundarum, o con el de falsum, o con la vis publica, bajo el imperio se convirtió en crimen especial y perfectamente diferenciado de los precedentes. Implicaba siempre la presencia de dolo en el delincuente, la amenaza de un peligro futuro, inminente, sin que fuera precisa la violencia material; presuponía el uso de un derecho que no existía, más que en apariencia, tal como aparece en el fragmento del jurisconsulto D. 47, 13, 2, y en la Collatio 8, 7, 2. Los romanos no han facilitado una definición precisa del crimen, que se castigaba por los magistrados imperiales extra ordinem, es decir, arbitrariamente. No hay concordancia entre los juristas modernos acerca de la noción de concussio, por lo que es preciso atenerse a los ejemplos facilitados por las fuentes: 1. Simulando una orden del gobernador de la provincia. 2. Tomando las insignias de un oficio civil o militar, pero en este

55 "Impp. Gratianus, Valentinianus et Theodosius AAA. Theodoro defensori civitatis. In defensoribus universarum provinciarum erit administrationis haec forma et tempus quinquennii spatii metiendum...Dat. 11 nonas Ianu. Constantinopoli Arcadio et Bautone cons."

56 HUMBERT, G., en Dictionnaire des antiquités D-S, t. III-Deuxième partie, Graz 1969, p. 1438, s. v. concussio. 
último caso se castigaba con pena de muerte a los humiliores, y deportación a una isla para los honestiores. 3. Amenazar con una acusación criminal, lo que permitía la aplicación de la ley Cornelia de falsis o de las penas de la calumnia. La restitución de los dineros extorsionados era independiente de la acción penal.

Más preciso, en la definición de la figura penal, es Mommsen ${ }^{57}$, quien sostiene que al menos, a partir del siglo II d. C., y sin supresión del procedimiento por el crimen repetundarum, la extorsión fue considerada como un delito independiente; es decir, se formó con ella el delito de concussio, de intimidación, consistente en constreñir a alguien a dar o prestar algo, abusando al efecto del poder oficial que el opresor tenía en sus manos. A mediados de época imperial, los magistrados-jueces fijaron la pena que había de imponerse, en estos delitos de los empleados públicos, a discreción suya. Unas veces se usa el termino de crimen de repetundis, y otras el de concussio, "esto es, el correspondiente a la verdadera extorsión", aunque normalmente se aumentaba la pena, superior a lo que se hubiere recibido por la extorsión ${ }^{58}$.

En idéntico sentido se pronuncia Falchi ${ }^{59}$, para quien, además del genérico crimen público de repetundis, se puede incurrir en el crimen específico extraordinario de concusión, el cual, siguiendo a la glosa a

\footnotetext{
57 MOMMSEN, Theodor, Derecho penal romano, Bogotá, Temis, 1976, p. 447.

58 MOMMSEN, Theodor, Derecho penal romano, op. cit., p. 455.

59 FALCHI, Giuseppino Ferruccio, Diritto penale romano, t. II. I singoli reati, Padova, Zannoni, 1932, pp. 183-184.
} 
C. Iust. 4, 7, 3, se produce cum aliquis occasione publici officii quod habet aliquid extorquet a subiectis ${ }^{60}$.

Uno de los términos que encontramos en la constitución es el de mercator, para el que Alberico de Rosate se limita a remitir a Bártolo y a las fuentes clásicas ${ }^{61}$, mientras que Andrés Alciato ${ }^{62}$ es más preciso, al señalar que "mercator est qui negociationis exercendae, quaestumque faciendi causa merces emit, ut vendat. Quapropter qui semel emit pannos, ut venderet, mercator non est: quia in eo deficit exercitium. Idemque et cum quis possessiones conducit... Sed et cum quis triticum, vinum, oleum, in agris suis collectum vendit, non ideo mercator est: non enim ab alio emit, ut vendat... Caeterum, et qui amplum patrimonium habens, in re modica negociatur, licet eius respectu mercator sit, non tamen huiusmodi privilegio fruetur... non videtur lex mercatorem accepisse, qui principaliter non sit, et ampliorem partem substantiae in mercimoniis non habeat».

Cuyacio $^{63}$ identifica a los mercatores con el grupo social de los «nobiliores y potentiores». Con su actividad, no realizan un negocio

${ }^{60}$ En casos particulares, referidos en D. 47, 13, 2, se configura la concusión incluso si no es cometida por un oficial público, por ejemplo, quien por lucro acusa a un inocente, o por lucro procede o no con una acusación, declara o no declara como testigo, cf. D. 3, 6, 8. Es evidente que una acusación quita a la otra.

${ }^{61}$ ALBERICUS DI ROSATE, Dictionarium iuris tan civilis quam canonici, Venetiis, apud Guerreos, 1573, reimpr. anast. Roma, La Bottega d'Erasmo, 1971, p. 471, s. v. Mercator: et quis mercator: Bartolus, in lege legatis FF. De legatis 3, D. 32, 1, 65 et rubrica digestorum et in rubrica $C$. de naviculariis ; Código Iust. 11, 2 et in tractatu de testi. ver. 36.

62 ALCIATO, Andreas, Opera omnia, t. I. De verborum et regum significatione libros quatuor, Basileae, ex off. Isingriniana, 1558, reimpr. Frankfurt am Main, Vico Verlag, 2004, cols. 386-387.

63 CUYACIO, Jacques, Paratitla in librum IV Codicis Iustiniani, tit. XVIII. De commerciis et mercatoribus, en Operum, t. II, Neapoli, typ. Moriana, apud V. Pauria, 1758, col. 302: "Commercium est emendi vendendique invicem ius, quod et promercium dicitur. Mercatores sunt nobiliores et potentiores quos mercaturam facere non indecorum, cum sit contractus juris gentium... utiles reipublicae qui tabernam aut 
indecoroso, ya que al comprar y vender, llevan a cabo un contrato de derecho de gentes, y con su mediación ejercen un servicio importante a la república, aunque no lo realicen personalmente, sino por medio de los factores o institores, sin que se les pueda identificar con los comerciantes al detal.

Aunque no aparecen expresamente citados en la constitución, esa función de custodia del territorio más próximo al mar, se encargaba a los custodes litorum et portuum, y se complementaba con la de los curiosi, respecto de los cuales observa Di Paola ${ }^{64}$ que su actividad era polivalente, no circunscrita al campo penal, con la puesta en prisión preventiva de los culpables, o al sector de correos, sino que abarcaba el campo fiscal y el comercial, tal como aparece en la constitución del año 412, C. Th. 6, 29, 10. El emperador Honorio, abrogando una constitución precedente, demandada por el magister officiorum, con la cual se fijaba el número de inspectores que debían enviar a las provincias, y que no se ha conservado, dispone el retorno a la antiqua consuetudo, y ordena que todos los curiosi idonei sean enviados a diversas regiones, en las provincias, en las costas, en los puertos y en otros lugares, es decir, en todo el imperio. Debidamente instruidos y con los correspondientes mandatos sobre los controles que debían efectuar, ejercitan su función sobre la base de la autoridad de esta ley. Cada curiosus debía, entre otras cosas, actuar de modo que

negotiationem exercent, plerunque per institores... magnam copiam Mercatores separantur ab his qui cellam vini aut olei vendunt, scilicet minutatim".

${ }^{64}$ DI PAOLA, Lucietta, I curiosi in età tardoantica. Riflessioni in margine al titolo VI,29 del Teodosiano, en AA. VV., Le Code Théodosien. Diversité des approches et nouvelles perspectives. Études réunies par Sylvie Crogiez-Pétrequin et Pierre Jaillette, Rome, École Française de Rome, 2009, pp. 131-132. 
procurase ejercitar bien lo que se le había encargado, afirmando Di Paola: "A me sembra che questa disposizione - a cui per molti versi è vicina un'altra di Teodosio II" (VII, 16, 3 del 420) que instituye los custodes litorum et portuum, quienes ejecutan su tarea junto a los curiosi, muestra claramente cómo los últimos pudieron ejercitar funciones de inspección al mismo tiempo. El control fiscal, comercial y viario en todo el imperio viene en ese momento ejercido sin limitación numérica alguna, conforme a la antiqua consuetudo, en el sentido que en las provincias son enviados todos los curiosi idonei, es decir, aquellos que se han distinguido por labor et ordo militiae, como lo había dispuesto Constancio II en las constituciones del año 359, C. Th. 1, 9, 1 y 6, 29, 4, en las cuales, para su nombramiento, está prohibido el recurso al sistema del sufragio, mientras se prima el servicio y el rango.

Entendía Godofredo ${ }^{65}$, que, ateniéndonos a las disposiciones referidas en el Código de Teodosio II, el cuidado y vigilancia de los lugares, incluidos los litorales y puertos, se asignaba muchas veces a los "domesticos y protectores", pero de modo singular se nombró a los custodes para la vigilancia de puertos y litoral: "litorum nominatim et portuum et itinerum custodes quidam erant, et excubias agebant", tal como vemos en C. Th. 7, 16. En su opinión, se entiende por "litora scilicet, id est, portus, stationes, quin et insulae", es decir, puertos, bahías o fondeaderos e islas, a tenor de C. Th. 7, 16, 1 y 2, pero también C. Th. $11,2,5 ; 8 ; 17$ y 34 , de naviculariis 66 .

${ }^{65}$ Codex Theodosianus, cum perpetuis commentariis Jacobi Gothofredi,..., op. cit., p. 254. 66 Sobre los diferentes cargos administrativos del Bajo Imperio que inspeccionaban, vid. DI PAOLA, Lucietta, Per la storia de gli "occhi del re". I servizi ispettivi nella Tarda Antichità, Mesina 2005. 


\section{CONTEXTO HISTÓRICO-POLÍTICO Y SOCIO- CONÓMICO QUE DETERMINA LA EMANACIÓN DEL PRECEPTO LEGISLATIVO}

A la muerte del emperador Cómodo, el año 19267, el senado eligiócomo sucesor a Pertinax, general de Marco Aurelio, quien se apoyó en el senado para su ascenso y gobierno, pero ello provocó el descontento de los pretorianos, siendo asesinado. Entonces, estos últimos anunciaron que darían el trono a los aspirantes que hicieran el regalo más espléndido a sus soldados, entrando en conflicto las legiones británicas, mandadas por Clodio Albino, junto a las siríacas, bajo Pescennio Niger, y a las ilíricas, comandadas por Septimio Severo. Este último marchó sobre la capital, convirtiéndose en nuevo emperador, porque el senado depuso a Juliano y lo hizo apuñalar. Para vengar la muerte de Pertinax disolvió la guardia pretoriana y Septimio Severo venció a sus rivales pretendientes al trono, castigando sangrientamente al Senado, por haber simpatizado con sus dos contrincantes, Pescennio Niger y Clodio Albino.

Uno de los escritores de la Historia Augusta, Elio Esparciano, deja constancia de este período y graves incidentes, con ejercicio cruel de las armas y del poder militar, no solamente contra los jefes opositores sino contra cualquiera que asumiera protagonismo en contra del

${ }^{67}$ Cf. NACK, Emil - WÄGNER, Wilhem, Roma. El país y el pueblo de los antiguos romanos. Trad. por J. Godo Costa, $2^{\mathrm{a}}$ ed., Barcelona, Labor, 1966, pp. 513-515: Septimio Severo. 
vencedor, incluso respecto de los mismos soldados, como vemos en el apéndice de la vida de Septimio Severo ${ }^{68}$.

Al relatar los hechos que tuvieron lugar entre Septimio Severo y Pescennio Negro, especialmente después de la batalla final cerca de Alejandría, en la lucha por la sucesión al trono, en la que Pescenio perdió sus posibilidades de gobierno, afirma dicha fuente literaria: "el combate fue tan largo, tan obstinado y tan grande la matanza, que los ríos de la llanura corrieron durante algún tiempo hacia el mar más abundantes en sangre que en agua; pero al fin venció el ejército de Severo... Niger corrió apresuradamente a Antioquía con algunos amigos suyos, de los más nobles... se ocultó en una casa de los arrabales, donde le encontraron unos jinetes del ejército enemigo, que iban en persecución suya y que le cortaron la cabeza. Así pereció Niger... Después de su muerte, Severo hizo matar no solamente a los que siguieron su partido, sino también a los arrastrados por la necesidad o las conjeturas. Solamente perdonó a los soldados que habían huido al otro lado del Tigris, y que no regresaron hasta que les concedió el perdón. Muchos pasaron a los bárbaros, y desde entonces aprendieron éstos a combatir a pie firme con los romanos" 69 .

Esto explica la primera migración de soldados fuera del Imperio, en beneficio de los persas, y la transmisión de conocimientos militares para un pueblo hostil al romano ${ }^{70}$, con la promoción de sus recursos

68 ELIO ESPARCIANO, Escritores de la Historia Augusta, trad. del latín por F. Navarro y Calvo, Madrid, Sucesores de Hernando, 1919, pp. 288-289.

${ }^{69}$ Cf. Pescenius Niger (193-194), Historia Augusta. Römische Herrschergestalten, t. I, von Hadrianus bis Alexander Severus, Zürich und München, Artemis, 1976, pp. 216218.

70 Cf. STARR, Chester, Storia del mondo antico, trad. del inglés, $2^{\mathrm{a}}$ ed. riv. E agg., Roma, Editori Riuniti, 1977, pp. 656-657. 
bélicos, entre los cuales se encuentra la utilización del hierro en la fabricación de armas, que va a ser uno de los productos que Roma prohíbe exportar ya en ese período, como vemos en el Digesto, en un fragmento de Ulpiano.

La anarquía militar del siglo III d. C., y las disputas por la sucesión en el poder del siglo IV, permitieron la progresiva entrada de los pueblos bárbaros en territorio romano, aunque en ocasiones no se hizo de forma pacífica, dando cauce a las invasiones de comienzos del siglo V. En los años 400-40271, los emperadores de Oriente y Occidente negociaban, en régimen de igualdad, con los jefes rebeldes de los pueblos bárbaros, a pesar de lo cual hubo grandes incursiones de los pueblos septentrionales de Europa, especialmente de los hunos, a todo lo largo del Danubio ${ }^{72}$. La capital de las provincias de las Galias y la residencia del prefecto del pretorio se transfirió de Trèves en Arles, lo que equivalía a una rendición, y la del emperador de la parte Occidental, de Milán a Ravenna. El año 406, una masa unida de media docena de tribus, con los vándalos a la cabeza, junto con los alanos, suevos y burgundios, entre otros, tomaron posesión

\footnotetext{
71 Vid. MACMULLEN, Ramsay, Le déclin de Roma et la corruption du pouvoir. Trad. de l'anglais par A. Spiquel et A. Rousselle, Paris, Les Belles Lettres, 1991, pp. 290294.

72 En criterio de Huvelin -(HUVELIN, Paul, Estudes du Droit comercial romain (histoire externe - Droit maritime, París, Sirey, 1929, p 67)-, después de la gran invasión de los Hunos, Teodosio para pacificar Oriente, insta a los Godos a instalarse en la ribera izquierda del Danubio, hacia la parte Occidental. A su muerte, el año 395, el Imperio se divide entre sus hijos Honorio, en Occidente y Arcadio, en Oriente, de modo que la decadencia se acelera, porque el año 414, se funda en las Galias el reino de los Burgundios; el año 419, el reino de los Visigodos; el 429 los vándalos dominan el Norte de Africa, y el 476 cae definitivamente el Imperio romano de Occidente por Odoacro, rey de los Hérulos, instalándose los Ostrogodos en Italia, el año 493.
} 
de Germania, la Galia y España El año 408, Alarico hizo su segunda invasión de Italia, y el año 409 los visigodos penetran en España sin oposición, pero el año 410, Alarico lleva a cabo el saqueo de Roma, aunque no pudo pasar a África por carecer de barcos. A su muerte, Ataúlfo condujo a los godos a la Galia, y más tarde a España.

Estos hechos no se pueden comprender sino por el enfrentamiento directo y de ruptura surgido ${ }^{73}$ entre el todopoderoso ministro de Honorio, Stilicón, y el de Arcadio, el eunuco Eutropio. El general Stilicón para protegerse contra la pars Orientalis del Imperio, separó en dos el mundo Mediterráneo ${ }^{74}$, aislando Occidente de Oriente, a través de una serie de medidas diversas, con objeto de evitar las infiltraciones orientales en Italia. Con este objetivo, puso en marcha la organización de una vigilancia militar muy estricta de puertos y costas, en particular en Italia. Después de la caída de Stilicón, el año 408, estas medidas fueron abolidas, como refiere C. Th. $7,16,1$, pero mientras estuvieron vigentes, $\mathrm{y}$ años inmediatamente posteriores, debieron comportar un golpe serio a la economía comercial del Mediterráneo ${ }^{75}$.

73 Cf. ROUGÉ, Jean, Recherches sur l'organisation $d u$ commerce maritime en Méditerrenée..., op. cit., pp. 487-488

74 Vid. DEMOUGEOT, E., De l'unité a à la división de l'Empire romain, 395-410. Essai sur le gouvernement impérial, París 1951.

75 Recuerda Piganiol, que en noviembre del año 401, Alarico invadió Italia del Norte y se presentó ante Milán, dando lugar a las batallas de Pollenza y Verona, el año 403. Merced a las victorias, se reconstruyeron los muros de Roma, y Estilicón, regente rechazó a Alarico en Iliria. El año 405, una horda, conducida por el godo Radagasio, cruzó el Danubio, y penetró hasta Italia, donde fue aniquilada. El 31 de diciembre de 406, partidas de vándalos, cuados, alanos, suevos y burgundios cruzaron hacia Maguncia, y se esparcieron por la Galia, destruyeron Estrasburgo, Reims, Amiens y penetraron hasta Toulouse. Los hunos se instalaron en Panonia y los burgundios en el Rhin. Alarico reapareció en Italia, y Estilicón, por discrepancias con otros poderes de la corte imperial, fue 
Entre los testimonios literarios que muestran la llegada de los pueblos bárbaros al Imperio romano, es muy clarificador un texto de Amiano Marcelino 76: “En este momento, como si las trompetas diesen la señal del combate a lo largo de todo el universo romano, pueblos muy bárbaros se ponían en movimiento y atravesaban las fronteras más próximas. Los alamanos devastaban al mismo tiempo la Galia y la Retia; los Sármatas y los Cuados, la Panonia; los Pictos, los Sajones, los Scots y los Atacotes atacaron Bretaña, con incesantes conflictos; los Austoriens y otros pueblos bárbaros llevaron a cabo correrías en África, con más violencia que de ordinario; los Tracios, incluso, eran objeto de saqueos por bandas de Godos, que se dedicaban al pillaje. El rey de Persia invadía Armenia, apresurándose, a base de inmensos esfuerzos, para someterla a su dominio, sin respeto alguno del

asesinado el 22 de agosto del año 408. Honorio reinó teóricamente en el Imperio Occidental entre el año 408 y el 423, de modo que, durante su mandato, Alarico se presentó frente a Roma el año 408 y exigió un pesado rescate, que le fue abonado. El 28 de septiembre del año 409, vándalos, suevos y alanos, después de devastar la Galia, pasaron a España. Ataúlfo se casó en Narbona con la hija de Teodosio, Gala Placidia, a quien llevó a Italia como rehén, mientras se multiplicaron los usurpadores, aunque el imperio romano se salvó gracias a un general, Constancio, en el año 411, quien se libró de los usurpadores, estableciendo a los visigodos en Aquitania, desde Toulouse a Poitiers, sin dejar de considerarlos como federados (año 418). Obligó a Placidia a casarse con él y se hizo proclamar Augusto en febrero del año 421. Teodosio II no lo reconoció, surgiendo un conflicto entre Honorio y Gala Placidia que debió exilarse a Oriente el año 423, muriendo Honorio poco después. Aunque Teodosio II había querido restablecer la unidad del Imperio, los cortesanos de Occidente eligieron emperador a uno de los suyos, Juan. Teodosio aceptó que fuera césar, el año 424, pero como Augusto, al hijo de Gala Placidia y Constancio, Valentiniano III, a quien instaló en el trono un ejército de Oriente.PIGANIOL, André, Historia de Roma, trad. del francés por R. Anaya, $3^{\mathrm{a}}$ ed., Buenos Aires, editorial universitaria, 1974, pp. 464-466.

76 AMMIEN MARCELLIN, Histoire, tome V (livres XXVI-XXVIII). Teste établi, trad. et ann. par Marie-A. Marié, París, Les Belles Lettres, 1984, 26, 4, 5-6 (años 364-366), p. 68. 
derecho, alegando el pretexto que después de la muerte de Joviano, con el cual había concluido un tratado de paz, nada le impediría entrar en posesión de lo que anteriormente había pertenecido a sus ancestros".

Demougeot ${ }^{77}$, al tratar de la crisis de principios del siglo $\mathrm{V}$, pone de relieve cómo contribuyeron a ello los pueblos germanos, orientales y occidentales, y los gobiernos de las dos partes del Imperio, unos pro-germanos y otros antigermanos, quienes fomentaron el enfrentamiento imperial de los titulares del poder político, al mismo tiempo que la división territorial permitió las invasiones de algunos de los pueblos germanos en el Imperio de Occidente, comenzando por los visigodos de Alarico, especialmente después de la muerte de Estilicón ${ }^{78}$.

Otro factor de resquebrajamiento del Imperio, y causa de enfrentamiento con otras poblaciones, fue el credo religioso, entre la ortodoxia católica y las doctrinas de las sectas heréticas ${ }^{79}$, como puso de manifiesto Zeiller ${ }^{80}$, particularmente a partir de Constantino, con los donatistas, los arrianos, el paganismo de Juliano, la declaración de Teodosio I del catolicismo como único credo del Imperio, y en la parte Occidental del Imperio, el priscilianismo y el pelagianismo, sin

77 DEMOUGEOT, Emilienne, La formation de l'Europe et les invasions barbares, t. II. De l'avénement de Dioclétien au debut du VIe siècle, París, Aubier, 1979, pp. 161-294: ${ }^{78}$ No se puede olvidar que desde Diocleciano había una gran cantidad de tropas en las fronteras, especialmente en el Danubio, pero sin la efectividad necesaria para contenerlos, verificable en los combates que se suscitaron.

79 Vid. GAUDEMET, Jean, La formation du droit séculier et du droit de l'Église aux IVe et Ve siècles, París 1979.

80 ZEILLER, Jacques, L'Empire romain et l'Eglise, París, E. de Boccard, 1928, pp. 6099. 
olvidar a los heréticos orientales del nestorianismo y monofisitismo, ya en el siglo V. d. C.

Para el problema que nos ocupa de la interpretación de la constitución teodosiana del año 420, es preciso partir, de cómo se difundió con rapidez el cristianismo entre los persas a mitad del siglo III d. C., gracias especialmente a misioneros de Edessa. Cuando subió al trono Sapor II, en el siglo IV, comienza una lucha incluso religiosa entre el Imperio romano, con gobernantes cristianos, y los persas, que acusan al pueblo nazareno, habitante en territorio del Imperio romano, de tomar partido a favor de los enemigos, pero ellos, a su vez, sospechan que los maniqueos eran espías de los persas ${ }^{81}$. Ello causó una dura persecución religiosa contra los cristianos, que se practicó ininterrumpidamente desde el año 339 hasta la muerte de Sapor II, el 379, generando multitud de mártires. Aunque su sucesor permite una paz interna del territorio, y suspende la persecución, realmente hasta el año 410, con el concilio de Seleucia, no hubo una situación de tranquilidad, que desaparece rápidamente en el reinado de Iazdgerd, con nuevas persecuciones, y se acentúa con su sucesor

\footnotetext{
${ }^{81}$ Los reyes sasánidas estuvieron fuertemente adscritos a la religión mazdeana, de modo que con Sapor II d. C. se produjo una gran lucha entre la monarquía oriental y el Imperio, que ya aceptaba la profesión libre de la creencia religiosa cristiana, si bien exigió, por medio de sus embajadores, que Constantino restituyera a los persas cinco provincias del otro lado del Tigris, que había conquistado Roma en tiempo de Diocleciano, a través de Galerio. Se suscitó una guerra en la parte Oriental, y ésta tomó rápidamente la perspectiva de una guerra religiosa, para la que Sapor II impuso una contribución doble a los cristianos, considerándolos extranjeros, y nombrando expresamente entre los afectados "le peuple nazaréen qui habite notre territoire", a los que acusó de tener su corazón con el Cesar, "notre ennemi". ZEILLER, Jacques, L'Empire romain et l'Eglise..., op. cit., pp. 100-107.
} 
Bahram primero, finalizando en el año 422, después de una nueva guerra contra los Romanos.

Huvelín ${ }^{82}$, destaca cómo en este período el comercio pierde toda su libertad. El Estado creía restablecer el comercio en su prosperidad anterior, pero realmente paralizó el mismo con su reglamentación minuciosa y estricta. El comercio se convirtió en una parte de la administración, porque el Estado considera como un deber la articulación de una buena regulación del comercio, para la buena administración económica del Imperio, y particularmente su avituallamiento. El ministro del tesoro público (comes scrarum largitionum) desempeña el oficio de ministro de comercio, de manera que, bajo sus órdenes, hay agentes, en pronvincias, como son los comites commerciorum, encargados de las compras de productos que le encomienda la Administración, además del cobro de los impuestos que deben aportar los comerciantes. En el régimen del comercio ${ }^{83}$, las necesidades de provisión son más precisas y apremiantes que antes, a causa de las requeridas por la defensa material y económica contra los bárbaros.

Señala Starr ${ }^{84}$, que la navegación era el principal medio de cambio de mercancías en el Imperio, por lo que numerosas naves, de transporte para el grano, partían cada año desde Alejandría y de África hacia Roma, y a veces se trataba de enormes buques de mil toneladas y más, pero más tarde también para Constantinopla. Otras

82 HUVELIN, Paul, Estudes du Droit comercial romain (histoire externe - Droit maritime, París, Sirey, 1929, p. 69.

${ }^{83}$ HUVELIN, Paul, Estudes du Droit comercial romain..., op. cit.,p. 72.

84 STARR, Chester, Storia del mondo antico, trad. del inglés, $2^{a}$ ed. riv. E agg., Roma, Editori Riuniti, 1977, p. 589. 
embarcaciones más pequeñas surcaban el Mediterráneo, especialmente en primavera y verano. Hacia Oriente, hombres aventureros navegaban a lo largo del Mar Rojo y pasando el golfo arábigo, llegaban hasta la India, aprovechando los vientos constantes estacionales, para llevar y traer de allí pimienta, especias, joyas y sedas.

Este planteamiento es compartido por De Martino ${ }^{85}$, ya que en la República, el comercio romano era intenso con las regiones italianas, y afectaba a múltiples productos, pero también con los países tanto del Mediterráneo como de Oriente. Aunque el comercio marítimo no resultaba cómodo a causa de las condiciones que entonces existían para la navegación, sin embargo fue muy utilizado porque los costos del transporte eran más bajos que los terrestres, y los precios de los fletes estaban en proporción inversa a la cantidad transportada, sin olvidar el tanto por ciento que percibían los intermedios del comercio.

Por lo que se refiere al comercio exterior ${ }^{86}$, el romanista italiano citado entiende que era muy abundante en productos tales como vino, aceite, trigo etc., incluso con las naciones extranjeras, no solo de Oriente sino del Norte de Europa, de dónde se recibían piedras preciosas, marfil, objetos artísticos, ébano, seda, especias, perfumes diversos, animales exóticos, destacando el comercio de la seda con India y hacia el Occidente con el de ámbar, proveniente del Mar del Norte y del Báltico.

85 DE MARTINO, Francesco, Historia económica de la Roma antigua, trad. del ital. por E. Benítez, vol. I, Torrejón de Ardoz, Akal, 1985, pp. 165-183.

86 DE MARTINO, Francesco, Historia económica de la Roma antigua..., op. cit., pp. 409-433. 
El servicio de la annona era estatal, pero privados los medios navales empleados, los cuales pertenecían a comerciantes y hombres de negocios, denominados navicularii, que podían ser propietarios de la nave o haberla alquilado, incluso por largos períodos, porque como recuerda Ulpiano hubo controversias sobre la interpretación de un contrato de alquiler in perpetuum, y un papiro egipcio habla de un alquiler de nave por 60 años $^{87}$. El navicularius podía regir directamente la nave y viajar con ella para vigilar las operaciones comerciales, derivando su nombre de la actividad como gestor de la nave, tal como aparecen en la República y primer período del Imperio; más adelante, su actividad normal aparece ligada al transporte de mercancías para servicios públicos: navicularii dicuntur qui transferunt frumenta in urbem aut ubicumque est imperator o imperatum. Al lado de la organización privada de la navegación ${ }^{88}$, y de los servicios particulares de los puertos, había un aparato público, con funciones administrativas y de control, en razón del interés público, afectando a los distintos géneros de bienes.

Moschetti ${ }^{89}$, destaca que se pasó de un sistema de libertad del comercio marítimo a otro de control del mismo por parte del Estado

\footnotetext{
87 DE MARTINO, Francesco, Historia económica de la Roma antigua..., op. cit., p. 420. Las relaciones comerciales se entablaban entre los funcionarios de la annona y los particulares, no con el colegio en su conjunto, aunque este último tendría la función política de garantizar de hecho la normalidad de los transportes, para lo cual se acudía habitualmente a beneficios y privilegios otorgados por los emperadores, como incentivos para asegurar ese tráfico, en lugar de optar por imposiciones coactivas.

88 DE MARTINO, Francesco, Historia económica de la Roma antigua..., op. cit., p. 423.

89 MOSCHETTI, Cesare Maria, Notae al libro de J. Rougé, Aspetti organizzativi dell'attività commerciale marittima nel bacino del Mediterraneo durante l'Impero romano..., op. cit., p. 410 y abundante bibliografía.
} 
a finales del siglo IV d. C., por un interés eminentemente fiscal, idea que comparte Jones ${ }^{90}$, especialmente por motivos de seguridad, tasándose muy severamente los derechos de importación y exportación, singularmente en el imperio de Oriente, en el cual el comercio exterior estaba sujeto al control de los comites commerciorum $^{91}$.

\section{ANÁLISIS DEL CONTENIDO Y ALCANCE DE C. Th. 7,}

\section{6,3}

Existe un principio jurídico en la clasificación de las cosas, proveniente del Derecho de gentes, y asumido por el Derecho romano, a tenor del cual el mar es res communis ${ }^{92}$, de modo que debe ser libremente utilizado por cualquiera, y no es susceptible de tráfico jurídico entre particulares, ni susceptible de apropiación, aunque las legislaciones modernas introduzcan nociones y un régimen jurídico que eran ignotos para el pueblo de Roma. A este régimen se refiere Godofredo93, cuando afirma: "mare in laxitate naturali et promiscuo

\footnotetext{
90 JONES, A. Hugo M. Il tardo impero romano, 284-602 d. C., op. cit., t. III, 1981, pp. 1262-1265 y 1638-1643, nota 7 y ss.

91 Uno para el Ilírico, uno para Mesia y Ponto y otro para Oriente y Egipto, y debía pasar a través de unos pocos lugares bien determinados. Klysna (Suez) era a veces el único puerto autorizado para el Mar Rojo y comercio con la India: en otros períodos Iotaba, isla en la parte septentrional del golfo de Acaba, era un destacamento aduanero. Había una campamento en Hieron, a orillas del Bósforo, para controlar el comercio del Mar Negro.

92 D. 1, 8, 2, 1. Marciano; Inst. Iust. 2, 1, 1 y 3: D. 8, 4, 13 pr. de Ulpiano.

93 GOTHOFREDI, Iacobi, De imperio maris et de iure naufragii colligendi legeque Rhodia, ex Iure romano, en Opuscula varia; iuridica, politica, historica, critica, Genevae, sumpt. Ioannis Antonij et Samuelis de Tournes, 1654, pp. 1-2.
} 
semper usu atque immetatum mansisse censent, veluti rem quae in nullius dominio, vel Imperio esse possit".

De los cuatro tipos de constitutiones que se promulgan en el Imperio, por decisión personal del Emperador 94 , edictos, decretos, rescriptos y mandatos, el primero tenía carácter general y se aplicaba a todo el Imperio o al menos a una región o grupo importante de personas, mientras el segundo, en sentido técnico, eran las sentencias del tribunal imperial, si bien abarcaba toda constitución imperial, como vemos en la terminología de C. Th. 7, 16, 3: decrevimus, aunque no había tal sentencia. El tercero eran contestaciones a cuestiones que formulaban particulares, funcionarios o jueces, y los mandatos eran instrucciones administrativas dirigidas a los funcionarios, destacando Gaudemet, que en época posclásica fueron utilizados el decreto y el rescripto uno por otro, ya que su proceso de elaboración era análogo, y los mandatos perdieron su función, porque las instrucciones a los funcionarios se hacían mediante leyes generales o cartas.

Giuffrè95, recuerda que el libro VII del Teodosiano ha sido considerado en gran parte, aunque no exclusivamente, como depósito de noticias del que se ha extraído el material que ha permitido reconstruir las estructuras económicas y sociales, y las respectivas medidas estatales y jurídicas desde la época de

\footnotetext{
94 IGLESIAS, Juan, Derecho romano, $12^{\text {a }}$ ed., Barcelona, Ariel, 1999, p. 35; PANERO GUTIÉRREZ, Ricardo, Derecho romano, Valencia, Tirant lo Blanch, 2004, pp. 8586; FERNÁNDEZ DE BUJÁN, Antonio, Derecho público romano, 22a ed., Madrid, Civitas, 2019, pp. 175-176; GAUDEMET, Jean, La formation du droit séculier et du droit de l'Eglise aux IVe et Ve siècles, 2a ed., París, Sirey, 1979, pp. 30-42.

95 GIUFFRÈ, Vincenzo, Iura e arma: Intorno al VII libro del Codice Teodosiano, Napoli, Jovene, 1979, pp. 4. y 8.
} 
Constantino, y los miembros de la comisión, encargada por Teodosio II pusieron el acento en los institutos publicísticos, entre los cuales están los relativos a de re militari.

No fue un mero obsequio a la tradición, sino producto de la compleja situación política del momento, a lo que se agregaba no solamente el temor a las circumlatrantes nationes, sino también la alta consideración de los arma, no inferior a los iura en sentido amplio. Las normas promulgadas por Teodosio II, promotor de la codificación, en materia militar, en la constitución de C. Th. 7, 16, 2, fechada en Constantinopla el 24 de abril del año 410, así como las relativas a la locorum et itinerum custodia, sirven de frontera no solo a la barbarica feritas, sino también al tyrannicus furor, que alimentase a cualquier usurpador, que tomara occassio a partir de las nuevas disposiciones, de modo que en la notificación oficial del Código Teodosiano, el 25 de diciembre del año 438, los senadores repitieron la propuesta del prefecto del pretorio: per vos arma, per vos iura, que luego reiteraría Justiniano en la constitución promulgadora de las Instituciones: non solum armis... sed etiam legibus oportet esse armatam, lo que se corregiría eliminando la confusio legum et iuris, entonces existente.

El romanista italiano, al que nos referimos, ${ }^{96}$ pone énfasis en la conveniencia de indagar los intereses específicos que conllevaron la abrogación del remedio adoptado por Estilicón, sobre la vigilancia armada del litoral y de los puertos: C. Th. 7, 16, 1, dada en Ravenna el año 408, considerado después hostis publicus ${ }^{97}$. Es conocido que la

\footnotetext{
96 GIUFFRÈ, Vincenzo, Iura e arma: Intorno al VII libro del Codice Teodosiano..., op. cit., p. 75, nota 95 .

97 GIUFFRÈ, Vincenzo, Iura e arma: Intorno al VII libro del Codice Teodosiano..., op. cit., p. 23, nota 22: debe recordarse la represión de la revuelta protagonizada por
} 
acusación de traición hecha contra Estilicón fue motivada en parte a causa de su política de alianza con algunos grupos bárbaros. También pudo aplicarse dicha norma contra los usurpadores Átalo (409-410, 414-415), Máximo (409-411), Jovino y Sebastián (411-413), apoyados respectivamente por Alarico y grupos de vándalos, alanos, suevos y burgundios, C. Th. 7, 1, 1, del año 323, cuya redacción es muy explícita:"si alguno con perversa complicidad ha proporcionado a los bárbaros la posibilidad de saqueo en daño de romanos, o dividido el botín hecho en otra manera, sea quemado vivo.

La ley primera del libro y título citado del Teodosiano, aboliendo radicalmente las medidas de vigilancia adoptadas por Estilicón, se apoya sobre una incomprensible iniquitas de la disposición, que no se especifica, y alude solamente de modo genérico a un enrarecimiento de los comercios. Hay que advertir que Teodosio, de acuerdo con su tío Honorio, impone de nuevo las acostumbradas vigilancias respecto de omnes stationes navium, portus, litora, omnes abscessus provincialum, abdita quin etiam loca et insulae. La clave interpretativa viene de C. Th. $7,16,3$, donde se precribe el uso de documentos de acompañamiento, y recomendando no poner obstáculos excesivos a la navegación con operaciones de control, explicitando la ratio: ne merces inlicitae ad nationes barbaras deferantur ${ }^{98}$.

Fermo apoyado por los donatistas, años 374-375. También se pudo aplicar la ley de Constantino, C. Th. 7, 1, 1, año 323, contra los que se levantaron en Panonia y Antioquía, juntamente con federados bárbaros y siríacos en particular, cuando estos ocupaban determinadas partes del territorio imperial.

98 Vid. C. Iust. 4, 41, 2. Imp. Marcianus, años 455-457. 
En la parte Oriental, señala Giuffrée9 ${ }^{99}$ encontramos una sociedad constitucionalmente más ordenada, menos atacada y perturbada por los conflictos con los pueblos bárbaros, lo que se deduce, a tenor de las constituciones del libro VII del Código de Teodosio, y leyes sobre controles de los puertos (C. Th. 7, 16, 2-3 de los años 410 y 420), que muestran cómo los emperadores de la Parte Oriental estaban mucho menos preocupados sobre este asunto, y adoptan medidas más cautas, respecto de las decisiones oscilantes que se observan en la pars Occidentis, en materia de locorum et itinerum custodia.

Pocos autores se han ocupado del texto referido en el Teodosiano como Jacobo Godofredo ${ }^{100}$. Las dos primeras constituciones del libro y título que nos ocupa, muestra la costumbre instituida de poner custodes en los puertos y litoral, lo que implicaba una minoración del comercio, tanto de bienes como de tránsito de personas.

En C. Th. 7, 16, 1101, se deroga íntegramente el novedoso y pormenorizado sistema de vigilancia en el litoral y puertos, impuesto por Estilicón ${ }^{102}$, para que no hubiera comercio alguno desde la parte Oriental con el Occidente del Imperio, presionado por los godos, cuya medida fue declarada por Teodosio y Honorio, a finales del año 408, como perniciosa, promulgando expresamente una libera facultas

\footnotetext{
99 GIUFFRÈ, Vincenzo, Iura e arma: Intorno al VII libro del Codice Teodosiano..., op. cit., p. 140:

100 Codex Theodosianus, cum perpetuis commentariis Jacobi Gothofredi..., op. cit., pp. 397-398: C. Th. 7, 16, 1.

101 CODICIS THEODOSIANI LIBRI XVI... adiectae sunt suis locis Aniani V. S. interpretationes..., Parisiis, apud Sebastianum Nivellium, sub ciconiis, 1586, pp. 157-158.

102 C. Iust. 8, 50, 20pr.
} 
de navegación en todo el Mediterráneo ${ }^{103}$, aportando su previsible fundamento:

Qua constitutione id unum agit Honorius, uti barbaris iam orbem romanum lacessentibus, communi inter romanos commercio, communioni, communicationi, charitati denique christianae, et mutuo compassui consultum iret: quo sane duae illae leges aperte spectant: immo et tertia praeterea, quam huic coniungendam pariter prorsus duco, lex 3 Cod. De commerciis, ut perniciosa custodia qua mercimonium seu commercium impediebatur, hac lege tollitur: et perniciosa in servitute retentio ingenuorum hominum.

Fallecido Estilicón, en agosto del año 408, el emperador Honorio abolió esas prohibiciones 104, y no duda en reconocer "qua re nova, insolita, iniqua, pernitiosa, commercium inter Imperium Orientale et Occidentale abruptum fuit... ac nominatim mercium variarum commercium abruptum fuerit, quae ex Oriente, et speciatim ex Syria in Occidentem comportabantur". En consecuencia, a partir de ese momento, se restableció la normalidad en el tránsito de mercancías entre las dos partes del Imperio, porque convenía a los dos emperadores, sin que rigiese el sistema de vigilancia precedente: "commeantur nempe, atque adeo commercij iure, inter utrumque Imperium, restituto: sane regulariter

103 Godofredo explica la actividad política desarrollada por Estilicón respecto de los bárbaros, y el objetivo propuesto con esta norma, "ne videlicet cuiquam ex Oriente in Imperium Occidentale pateret accessus".

104 "Caeso Stilichone, augusto mense Ravennae, unde haec lex data est, abolitum hac lege istud Stilichonis institutum ab Honorio fuit". 
cum inter Imperatores Orientis et Occidentis bene conveniebat, nulla in medio utriusque Imperij talis custodia erat".

La ley segunda del mismo libro y título del Teodosiano, comentada por Godofredo ${ }^{105}$, a diferencia de la anterior que se refiere a Occidente, calificando como perniciosa la vigilancia o custodia del litoral, viene considerada como saludable para la República, porque intenta proteger el Imperio de los usurpadores o tiranos, apoyados por pueblos bárbaros. Además, hay otra diferencia entre las dos disposiciones, ya que al establecer un sistema de curiosi en algunas regiones, con aprobación de Honorio, el año 410, Teodosio intenta proteger sus puertos, el litoral, los destacamentos e islas, de las invasiones bárbaras que provenían desde la parte Occidental del Imperio. La razón es clara: "Hac videlicet ratione, ne ad Orientem quoque furor ille transiret". Consecuentemente, no permite el acceso desde Occidente, si el que acude a su territorio carece de la autorización expedida por Honorio, sea un naviero o un simple mensajero, porque el bárbaro no podía enviar legalmente embajadores, y aprovechaba la remisión de exploradores, bajo la apariencia de gestionar negocios particulares 106

105 Codex Theodosianus, cum perpetuis commentariis Jacobi Gothofredi..., op. cit., pp. 398-399 Ley 2, año 410: De litorum et portuum aliorumque locorum limitaneorum per Orientalis Imperij limitem custodia instituenda, est haec lex.

106 "Proinde nullum ex Occidentis Imperio venientem admitti vult Theodosius hac lege, nisi Honorij in Occidente Imperatoris litteris munitum: adeo quidem, ut si quas portitor, seu gerulus literas habeat, ad privatas quasdam Imperij Orientalis personas, eas literas consignatas ad se transmitti velit Theodosius: scilicet quia interdum ubi recta via legatos mitti non potest, mittuntur exploratores, qui privati negotij specie, legationem tegunt: quales sunt mercatores... Sicut Theodoius Iunior hac constitutione Orientalem limitem, seu Imperium suum Orientis, ab Occidentalibus exploratoribus munitum ivit". 
En criterio de Godofredo, de este mismo año es la norma contenida en C. Iust. 4, 63, 4, dirigida a Antemio, prefecto del pretorio, porque complementa la ley precedente, con similares planteamientos, y se refiere a las relaciones con los persas, con los cuales Teodosio II había suscrito un tratado, disponiendo: "los comerciantes, así de nuestro imperio, como los sujetos al rey de Persia, no podrán celebrar ferias sino en los lugares que hemos convenido, para que no escrudiñen los secretos de otro reino, cosa que no es conveniente". Las mercancías, que no se negociaran en esas ferias, serían reivindicadas para el erario, y los contraventores sufrirían la pena del destierro, aplicando incluso penalidad pecuniaria a los jueces y alguaciles que tolerasen ese tránsito a lugares prohibidos para comerciar. Quedaban excluidos, de lo previsto en la ley, aquellos que acompañaran a los embajadores persas, y que hubieran llevado consigo mercancía para negociarla, los cuales estaban facultados para comerciar en cualquier parte, salvo que aprovechando esa embajada residieran mucho tiempo en una provincia, y no retornaran con su legado, afectando la pena prevista a quienes contrataran con ellos durante su residencia.

La ley 3 del mismo título y libro en el Teodosiano ${ }^{107}$, que motiva nuestra comunicación, insiste en un principio de transporte marítimo que ya había sido enunciado precedentemente, pero añade requisitos formales para cualquier expedición marina: los responsables de los barcos no sufrirían ninguna extorsión ni daño, se supone personal y

107 Codex Theodosianus, cum perpetuis commentariis Jacobi Gothofredi..., op. cit., pp. 399-400: ley 3: Saluberrima sanctione decrevimus... ad quas partes navigaturi sunt et quod nullam concussionem pertulerunt... año 420. 
patrimonial, si antes de iniciar su viaje comunican, en presencia del responsable militar y del defensor de la plebe, el destino de la nave, y que no han sufrido ninguna concusión, es decir, ningún tipo de violencia para efectuar esa manifestación.

Godofredo, compara este precepto del Teodosiano con la norma contenida en el C. Iust. 12, 44 (45), 1, con la adscrición de los custodes o curiosi de puertos y litoral por parte de Teodosio II, y cree que presenta concomitancia con C. Iust. 8, 10, 10, permitiendo a los que tuvieran propiedades, en las zonas fronterizas con pueblos bárbaros, que pudieran rodear sus fundos o terrenos con un muro, así como en las demás provincias, de modo que parece señalar la causa de C. Th. 7, 16, 3: libertad de navegación.

El humanista insiste que se trata de navíos que salen de puertos o litoral en zona de frontera, y por ello, "remitti naves dicuntur, quae e portu seu litore limitaneo emittuntur", de forma que el resto del precepto legislativo del año 420 queda sin modificación en Justiniano: “caetera ita Tribonianus immutavit: "Ita tamen ut earum Naucleri deponent, in quam provinciam ituri sunt, ut hoc manifestato, nulla contra eos postea indignatio seu concussio quoquo modo procedat".

Por este motivo, no duda en sostener ${ }^{108:}$ " mercibus et mercatoribus observandis, litorum et portuum custodes, sive curiosi, puta protectores, et ducis limitis officiales in limite Orientali, ne videlicet merces inlicitae ad Nationes Barbaras deferrentur, hac quoque constitutione Theodosius iunior disponit; eorumque simul officium instruit anno Domini 420 propter persas, videlicet cum quibus per haec tempora res fuit", tal como indica la

108 Codex Theodosianus, cum perpetuis commentariis Jacobi Gothofredi..., op. cit., p. 400 . 
constitución de C. Iust. 8, 10, 10, del mismo año, porque entonces se permite, en las provincias próximas a Persia, que los ciudadanos puedan levantar muros en terrenos de su propiedad, "repellendis, videlicet, submovendisque persis: hoc ita duplici obice a Theodosio hoc tempore Persis opposito".

En la Constitución justinianea 12, 44 (45), 1, Lucca da Penna109 comenta que en la misma se trata de la custodia de caminos y del litoral, para lo cual se nombran en este caso custodes de puertos y caminos, junto a los de provincia, de ciudad, etc. Su misión consiste en mantener indemne la cosa que deben guardar, sin que sufran hurtos ni otro daño, por lo que el custodio no puede dormir, como pastor sobre las ovejas, sino vigilar, si bien en sentido propio se designa "ad custodiendum ea quae alias salva esse non possunt", por lo que debe tener conocimiento del objeto que se le confía, sin que pueda abandonarlo incautamente, e incluso defendiéndolo hasta exponerse a la muerte, a fin de que se conserve bien lo que se le manda vigilar: "Custos adhibetur ut res commissa sibi salva sit, nec alij malum inferat, nec sibi ipsi exitio sit".

Juan Platea, comentando el mismo precepto ${ }^{110}$, parte del oficio desempeñado por el custodio de fronteras, incluso marítimas, matizando "quia ad milites spectat habere custodiam ne barbari cuiuscunque nationis romanum invadans imperium: sed etiam ne aliquid portetur ad eos propter quod efficerentur validiores ad praedictam

109 LUCCA DA PENNA, In tres posteriores libros Codicis Iustiniani, Lugduni, apud Ioannam Iacobi Iuntae filiae, 1582, pp.901-902.

110 PLATEA, Joannes de, Super tribus ultimis libris Iustiniani Codicis Commentaria: noviter castigata et emendata. Ornataque annotationibus atque additionibus marginalibus per magistrum Ioannem de Gradibus, Lugduni, Jacobus Myt, sumpt. Bart. Trot, 1516, fol. 129v: De litorum et itinerum custodia. Rubrica. 
invasionem, C. Iust. 4, 41, 1 de Valentiniano, Valente y Graciano (370375), et D. 39, 4, 11, de Paulo, ideo hic subijcit de custodia littorum et itinerum per quae loca portarentur praedicta".

Después de recordar el tenor literal de los preceptos contenidos en C. Th. 7, 16, 3; C. Iust. 4, 41, 2 y C. Iust. 4, 41, 1-2, pasa a examinar las penas previstas en el Ius Commune, y el modo previsto en las constituciones del Imperio romano, para no incurrir en sanción alguna, tanto del Derecho canónico como del justinianeo, correspondiendo al primero la excomunión: "De iure vero canonico est pena excommunicationis et omnium bonorum publicationis et efficiuntur servi capientium etiam tamen de suo quantum lucrari sunt dare debent in subsidium terre sancte. Sed notatur hic quod custodes apponendi sunt in littoribus maris et fluminum et itineribus terrarum per quae possunt merces illicite portari et possunt portantes detineri donec declarent ad quam provinciam delaturi sunt de quo statibus iuramento ipsorum deferentium. Et an causa sui usus vel negotiationis deferantur statur iuramento deferentis nisi persone deferentis qualitas dissuaderet vel probatio etiam de opposito sit in promptu. An pro mercatoribus portantibus frumentum et alia blada per diversas partes si nolunt timere concussiones et molestidas custodum ut vadant coram iudice et declarent ei ad quam partem pergere voluerit et iudicis habita licentia nullam detentionem vel arrestationem patiantur, alias possunt detineri maxime si qua sit praesumptio contra eos ut quando extra viam publicam et consuetam reperiantur sicut portantes contra debitum".

Godofredo, en su Manual de Derecho111, comenta el libro IV del Código de Justiniano, por lo que recuerda que hay cosas que no

111 GOTHOFREDI, Jacobus, Manuale juris seu parva juris mysteria, ubi quatuor sequentia continentur Juris civilis romani... Florilegium sententiarum juris... ex Corpore Justinianeo desumptarum. IV. Series librorum et titulorum in Digestis et in 
pueden ser materia de compraventa, pero también existen 112: "res quaedam seu species in Barbaricum (id est ad hostes) etiam induciarum tempore exportari ijsque vendi non possunt, veluti arma, ferrum, vinum, oleum, liquamen, atque id genus alia quibus hostes armari alive possunt, titulo 41".

Marquard afirma, sin ambages, que todas las personas conocen la utilidad y necesidad máxima que representa la actividad de una nave para una República, como instrumento de comercio ${ }^{113}$, por lo que en Roma fueron las personas particulares las que tuvieron estas naves, y los Emperadores favorecieron que las construyeran con importantes privilegios, a excepción de los senadores y gobernadores provinciales, para que no mezclaran los asuntos de gobierno con otros mercantiles, aunque esta actividad proporcionaba grandes rentabilidades, lo cual no impide que el poder político destine el bien privado a un uso público, a causa de una utilidad general que lo exija.

Dada su importancia y transcendencia, a nivel normativo se impuso la pena capital para los que enseñaran a los bárbaros a construir naves, cuando todavía ellos ignoraban ese oficio114, "quale interdictum anno 1563 communi Hanseaticorum decreto publicatum fuisse adversus Moschorum tunc temporis tyrannum Johannem Basilides"115.

Codice, $11^{\mathrm{a}}$ ed., auct. et accur., Genevae, sumpt. Gabrielis de Tournes et fil., 1726, pp. 518-524.

112 GOTHOFREDI, Jacobus, Manuale juris seu parva juris mysteria..., op. cit., p. 427. 113 MARQUARD, Johannes, Tractatus politico-juridicus De iure mercatorum et commerciorum singulari, Francofurti, imp. Thomae M. Götzÿ, 1662, pp. 222-226.

114 MARQUARD, Johannes, Tractatus politico-juridicus De iure mercatorum et commerciorum..., op. cit., p. 226.

115 MARQUARD, Johannes, Tractatus politico-juridicus De iure mercatorum et commerciorum..., op. cit., p. 230: “Nicolaus Boërius, prima quaestio, num ligni appellatione contineatur navis; ita, quod prohibite vendere et extrahere lignum extra territorium, naves non vendere possint? 
Marquar interpreta que si las mercancías no están prohibidas, ni hacen más fuertes a los enemigos, como es el caso de objetos de lujo, "non obstante offensionem extranei mercatoris esse plane illicitam, etiam iuri naturae et gentium, ex quo commercia orta sunt", y se pregunta por la posibilidad de exportar tabaco, en época de guerra, ya que hubo controversia doctrinal entre los españoles y los ingleses, porque los primeros entendían que debía ser confiscado, mientras los segundos, con testimonio de médicos, negaban que fuera un alimento la hierba de la nicotina.

Por lo que se refiere a las "merces illicitae" de la constitución imperial, Cuyacio ${ }^{116}$, al comentar el título noveno del libro 34, sobre los indignos, no duda en afirmar que todo ese título se refiere al derecho fiscal, porque los bienes que se quitan al indigno pasan al fisco, y señala que son "quasi illicitae merces", para especificar: "merces illicitae sunt arma, cotes, ferrum, vinum, frumentum, oleum, sales, liquores, si exportentur hostibus ${ }^{117 "}$, a los que se añade, por los griegos, el pez. También los eunucos, la púrpura y la seda, que si se decomisan pasan al fisco, y su persecución abarca incluso al heredero, ratione mercium, al igual que ocurre con otros crimina, como el repetundarum ratione pecuniae, o los de suposición de partos o el peculatus: "merces in commissum cecidisse fisco defertur". En otro lugar, alude al texto de Marciano, en uno de cuyos fragmentos transmite el rescripto de los

116 CUYACIO, Jacques, Notae ad librum XXXIV Digestorum, tit. IX, en Operum, t. X, Neapoli, typ. Moriana, apud V. Pauria, 1758, col. 478. Cf. CUYACIO, Jacques, Recitationes solemnes, ad titulum IX. De his quibus ut indignis, liber XXXIV Digestorum, en Operum, t. VII, Neapoli, typ. Moriana, apud V. Pauria, 1758, col. 1478.

117 D. 39, 4, 11; C. Iust. 4, 41, 1-2; 12, 44 (45), 1; 
emperadores Septimio Severo y Antonino Caracalla, a tenor del cual que el liberto era privado, como indigno, del legado o fideicomiso que le había dejado el patrono en el testamento, cuando había denunciado a su patrono, después de su muerte, como negociante en mercancía ilícita, aunque hubiera obtenido el premio.

Comentando el título 61 del libro cuarto del Código justinianeo118, no duda en afirmar "quia igitur multae sunt merces illicitae, eas oportet profiteri, et publicanus eas scrutari potest an sint licitae necne: merces illicite fisco committuntur, merces licitae improfessae etiam fisco committuntur".

Vismara ${ }^{119}$ establece una diferencia importante entre el comercio de productos ilícitos en época clásica y en época posclásica. Desde su punto de vista, la lex Iulia de maiestate fue el apoyo que encontraron los juristas clásicos para configurar el delito de contrabando de bienes con los que hacer la guerra ${ }^{120}$. Cervidio Scevola coloca entre los crímenes que caen bajo la sanción de la ley antes citada, la cesión a los enemigos del pueblo romano de todas aquellas mercancías, desde las vituallas a las armas, desde los caballos al dinero, desde los rehenes a las bestias de carga, y a cualquier otra cosa que habría podido convertirse en algo útil para la guerra contra Roma. Para perfeccionar el crimen es preciso el dolus malus facilitando a los hostes populi romani los medios útiles para la guerra adversus rem publicam: D. 48, 4, 3,

118 CUYACIO, Jacques, Ad titulum LXI de vectigalibus et commissis, libro IV Codicis, en Operum, t. IX, Neapoli, typ. Moriana, apud V. Pauria, 1758, col. 400.

119 VISMARA, Giulio, Limitazioni al comercio internazionale nell'Impero romano e nella comunitá cristiana medioevale, en Scritti in onore di Contardo Ferrini, pubblicati in occasione della sua beatificazione, vol. I, Milano, Vita e Pensiero, 1947, pp. 443-470.

120 VISMARA, Giulio, Limitazioni al comercio internazionale..., op. cit., p. 444. 
principio general, de Marciano, pero en particular, D. 48, 4, 4: cuiusve opera dolo malo hostes populi romani commeatu armis telis equis pecunia aliave qua de re adiuti erunt... cuiusve opera dolo malo factum erit, quo magis obsides pecunia iumenta hostibus populi romani dentur adversus rem publicam.

Paulo, siguiendo a su maestro Scévola, afirma que no es lícito proporcionar a los enemigos $=$ hostes, piedra para afilar el hierro, así como no es lícito darles hierro, trigo y sal: D. 39, 4, 11pr., "non sine periculo capitis licet", y se confirma en las Pauli Sententiae V, 1, 10. En este fragmento, se enuncian algunas de las principales mercancías indispensables para hacer la guerra, tal como se realizaba entonces, particularmente vituallas y metales, de los cuales el mundo romano estaba bien abastecido, mientras escaseaba en sus enemigos. Aunque no se cita la madera, es evidente que en aquel tiempo era muy importante para la guerra, y eso no quiere decir que fuera lícito darla a los enemigos.

En el elenco de Paulo, llama la atención que declare ilícito incluso el comercio de las piedras de amolar hierro, las cuales no venían referidas en el listado precedente. Paulo recupera el planteamiento de Cervidio Scevola, respecto de mercancías de ilícita exportación a los enemigos, como las vituallas, las armas en general y en particular caballos, dinero aliave qua de re adiuti erunt, incluyendo, dentro de estas aliae res, las acémilas. La enumeración de mercancías variaba según las circunstancias, pero se realiza siempre una mayor especificación. La ilicitud del comercio, respecto de estas mercancías, se afirma exclusivamente contra los enemigos u hostes, y habrá de 
aplicarse durante el período que duraba la guerra, a tenor de D. 39, 4, 11, 2 y Pauli Sententiae V, 1, 12-14.

A finales del siglo IV, una constitución de los emperadores Valentiniano, Valente y Graciano, prohibía transferir a cualquier territorio habitado por poblaciones bárbaras, fuera de los confines del Imperio -(bárbaro se opone a Romano, y todos los pueblos extraños al Imperio eran considerados bárbaros: se habla de barbarae nationes en C. Th,. 7, 16, 3 = C. Iust. 12, 44 (45) 1, impp. Honorius et Theodosius, año 420121)-, toda cantidad, incluso mínima, de vino, aceite, salsa de pescado en sal muera, ya que se habla de liquamen que recibe del pescado el sabor y olor característico, tanto como para ser usado como condimento ${ }^{122}$.

Entiende Vismara que quizás la prohibición de exportar vino y aceite se debe a la necesidad de que no faltaran estos productos en el ejército romano, y la conveniencia de conservar, a las poblaciones del imperio, todo aquello que podía servir para su sostenimiento. La prohibición de exportar el liquamen, en particular, atestigua de modo evidente que se intentaba eludir de esta manera la prohibición de exportar la sal, sancionada en D. 39, 4, 11 pr., llevando a los bárbaros el jugo de los pescados en sal muera, que podía ser utilizado para usos propios de la sal. Valentiniano corta el fraude, afirmando explícitamente la prohibición de exportar a los bárbaros, junto al aceite y al vino, también el jugo de los pescados en sal muera.

\footnotetext{
121 VISMARA, Giulio, Limitazioni al comercio internazionale..., op. cit., pp. 445-446, nota 4

122 VISMARA, Giulio, Limitazioni al comercio internazionale..., op. cit., p. 446: D. 4, 41, 1. Valentiniano, Valente y Graciano AAA ad Theodotum, magistrum militum, (años 370-375).
} 
Los mismos emperadores Valentiniano, Valente y Graciano, C. Iust. 4, 63, 2123, sancionaron la prohibición de entregar oro a los bárbaros en base a cualquier título, ampliando la lista de merces illicitae, al mismo tiempo que se hicieron cada vez más difíciles los cambios con los países que residían del otro lado de las fronteras del imperio. Más tarde se prohibió exportar púrpura, C. Iust. 4, 40, 1. Impp. Valentiniano Teodosio y Arcadio, y se dispuso un monopolio sobre el comercio de la seda: C. Iust. 4, 40, 2.

Lo más significativo fue que la prohibición del comercio de determinadas mercancías en época posclásica se aplicó a todas las poblaciones bárbaras, a diferencia de lo contemplado en el fragmento del jurista Paulo, en D. 39, 4, 11, en el que se configuraba un verdadero y propio contrabando de guerra, excluyendo la licitud de comerciar determinadas mercancías con los hostes, es decir, los enemigos declarados del imperio, lo que afectaba exclusivamente a los pueblos con los que Roma mantenía una guerra declarada. Valentiniano impone en el siglo IV una genérica prohibición de exportación de tales mercancías frente a cualquier pueblo extraño al imperio.

La defensa militar del imperio exigía que se sacrificase cualquier otro interés, incluso el de los cambios comerciales con el exterior ${ }^{124}$, porque era preciso un ejército fuerte, concentado en las fronteras, $y$ capaz de defenderlas frente a los bárbaros. Dado que todo pueblo de los confines era potencialmente un enemigo del imperio, y se iba acentuando la presión en las fronteras, consecuentemente todos los pueblos bárbaros vinieron considerados por Valentiniano como

123 VISMARA, Giulio, Limitazioni al comercio internazionale..., op. cit., p. 447. 124 VISMARA, Giulio, Limitazioni al comercio internazionale..., op. cit., p. 448. 
posibles hostes. De este modo se evitaba que el comercio con el exterior, aparte de privar al imperio de algunas mercancías, desde las vituallas a las armas, indispensables y siempre escasas, como consecuencia de las continuas carestías, pestes y guerras, pudiese nutrir a los eventuales enemigos y agresores, que habrían podido servirles para hacer la guerra contra el imperio.

La identificación del hostis con el barbarus ${ }^{125}$, y la extensión a éste de la prohibición de comercio, ya prevista frente al primero, implica necesariamente que el comercio de aquellas determinadas mercancías, con cualquier pueblo bárbaro, es ilícito, incluso si no existe un estado de guerra entre dicho pueblo y el imperio. Por tanto, no es un problema de contrabando en tiempos de guerra, sino una genérica limitación al comercio exterior, incluso valorada ante la posible hostilidad de los pueblos extranjeros frente al imperio. Mientras el crimen dell contrabando en caso de guerra, exigía el dolus malus del agente, para perfeccionar el nuevo crimen, recogido en las constituciones de Valentiniano, es suficiente que haya traspaso de mercancías al otro lado de la frontera.

El francés Rougé126, al tratar de las merces illicitae ${ }^{127}$, identificándolas con aquellas que tienen el comercio prohibido, recuerda que esta prohibición recae esencialmente sobre las

125 VISMARA, Giulio, Limitazioni al comercio internazionale..., op. cit., p. 448, nota 3: una completa inversión de los términos se produjo después de que los visigodos - que eran bárbaros- hubieron ocupado España. En la interpretatio de la Lex romana Visigothorum, el término barbarus, frecuente en las constituciones imperiales, se toma regularmente como hostis.

126 Cf. ROUGÉ, Jean, Recherches sur l'organisation du commerce maritime en Méditerrenée sous l'Empire Romain, París, SEVPEN, 1966, p. 505, 368-379 y 437-439. 127 ROUGÉ, Jean, Recherches sur l'organisation du commerce maritime en Méditerrenée..., op. cit., pp. 241 y 458. 
exportaciones con destino a países considerados enemigos, o susceptibles de serlo, es decir, los bárbaros, que están situados al otro lado de las fronteras del imperio, sin diferenciar los hostes de los barbari. La prohibición afecta, en tiempos de guerra, a los bienes de primera necesidad, o lo que es lo mismo, el trigo y los demás cereales, la sal y aquellos productos que se consideraban estratégicos, como el hierro y las piedras de afilar: D. 39, 4, 11 pr. y D. 48, 4, 3-4, que vienen recogidas en un texto de Paulo, jurisconsulto de los Severos, actualmente contenido en el Digesto, aunque hay fragmentos de las fuentes literarias que hacen pensar en una prohibición más amplia.

En consecuencia, dado que el Emperador utilizó los protectores para diversos objetivos, algunos de ellos fueron destinados a la frontera para que hicieran su custodia: "Ideoque apud hoc naucleri sive mercatores merces suas profiteri cogebantur, et gestis ad quas partes essent navigaturi, neque ante e portu sive litore dimittebantur: gestis apud Defensorem, praesente ipsomet Protectore", (quien había sido destinado a provincias para la custodia de los puertos y del litoral, en atención a la necesidad pública o de ejecución de algún mandato), o en presencia del oficial próximo al jefe militar del territorio, o $d u x$.

La segunda parte de la constitución de Teodosio 7, 16, 3, dispone que conste en acta que el nauclerus o mercator no han recibido concusión alguna, cuya circunstancia debe reflejarse en los documentos escritos que se redactan ante el defensor civitatis, presente el curiosus o el protector. Esta normativa se corresponde con el oficio asumido por el defensor: "unumquemque ab improbitatibus insolentum vindicare, qui publici officij specie alios concutere ferme solebant", a lo que se refieren las constituciones insertas en C. Iust. 11, 2, 1 y 3. 
Alberico de Rosate ${ }^{128}$, citando a Bártolo de Sassoferrato, al comentar la constitución de Constancio y Juliano, del año 357, defiende el alcance de la normativa posclásica, puesto que "nullam vim oportet navicularios sustinere", y lo explica siguiendo el texto de la ley: Es conveniente que no soporten violencia alguna los patronos de naves que transportan las especies de las annonas delegadas, y que no sufran concusiones ni algún otro género de incomodidad, sino que disfruten de toda seguridad al ir y al volver; debiéndoseles imponer la multa de diez libras de oro a los que hubieren intentado molestarlos. Dada en Roma en las calendas de junio, bajo el noveno consulado de Constancio y el segundo de Juliano, Cesar. Año 357.

\section{RECEPCIÓN DE LA LEY TEODOSIANA EN EL CÓDIGO DE JUSTINIANO Y ALGUNAS DE SUS APLICACIONES HASTA LA EDAD MODERNA}

Justiniano acogerá la constitución imperial de Teodosio y Honorio $^{129}$, y simplificará muchísimo su régimen, reduciendo tales controles, exigidos en la custodia del litoral y de los caminos:

Impp. Honorius et Theodosius AA. Eustathio pp. Saluberrima sanctione censemus, ne merces illicitae ad nationes barbaras

\footnotetext{
128 ALBERICUS DI ROSATE, Dictionarium iuris tan civilis quam canonici, Venetiis, apud Guerreos, 1573, reimpr. anast. Roma, La Bottega d'Erasmo, 1971, p. 502: navicularius: quod modis sumitur, Bartolus en la ley 1 C. de navicul. lib. 11: C. Iust. $11,2,1$.

129 C. Iust. 12, 44 (45), 1. De litorum et itinerum custodia. No fue comentado por Azón en su Lectura super Codicem, que pase del título 43, de tironibus, al título 45, de desertoribus et occultatoribus eorum.
} 
deferantur. Et quaecumque naves ex quolibet portu seu litore dimittuntur, nullam concussionem vel damna sustineant: ita tamen, ut earum naucleri deponant. In quam provinciam ituri sunt, ut hoc manifestato nulla contra eos postea indignatio seu concussio procedat. D. XIIII kal. Octob. Constantinopoli Theodosio A. VIIII et qui fuerit nuntiatus. (Año 420).

Pocas son las variantes que observamos entre ambos fragmentos. Algunas son irrelevantes, como la sustitución del decrevimus de Teodosio propia de la jurisprudencia primera del Principado, por otra que asumió más frecuentemente el legislativo justinianeo de censemus, de carácter preceptivo, utilizado por los compiladores, y objeto de explicación en D. 50, 16, 11130. Sin embargo, la redacción justinianea de la constitución del siglo $\mathrm{V}$ supone un cambio fundamental, en cuanto a la identificación y número de requisitos formales exigidos al armador para evitar cualquier disputa, extorsión, sanción o daño durante el viaje marítimo, ya que no alude a la redacción de documentos, ni a la concurrencia de las personas privadas junto a los representantes del poder político, y se limita a la mera declaración del destino de la nave antes de su partida ${ }^{131}$, ya que ello evita cualquier indignatio del poder político o un perjuicio patrimonial ${ }^{132}$.

130 "Javoleno, libro sexto ex Cassio. 'Censere' est constituere et praecipere. Unde etiam dicere solemus 'censeo hoc facias' et 'semet aliquid censisse...".

131 "Ita tamen, ut earum naucleri deponant, in quam provinciam ituri sunt, ut hoc manifstato, nulla contra eos postea indignatio seu concussio procedat".

132 La traducción francesa de Tissot (Les douze livres du Code de l'Empereur Justinien, de la seconde édition. Trad. en français par P.-A. Tissot..., t. IV, Metz, 
Para el comentarista del Ius Commune, Bártolo de Sassoferrato ${ }^{133}$, lo importante de la norma es la declaración que debe hacer el nauclerus, que lleva en su nave trigo y otros productos similares, para evitar que sean acusados de concusión, recurriendo a su manifestación ante el oficial de la localidad, identificando el puerto de destino, ya que ello le evita cualquier extorsión o penalidad que le quiera aplicar la autoridad política o funcionarial.

Luca da Penna ${ }^{134}$, por su parte, al analizar los tres últimos libros del Código justinianeo, y los vocablos más relevantes ${ }^{135}$, el poder político trataba de asegurar mediante custodia los litorales y caminos, con especial atención al puerto, definido por el jurista como "locus ubi est tutissima navium statio", o lugar de amarre de los barcos, y desde el cual se envían las naves, que no pueden iniciar su viaje marítimo y levantar anclas sin obtener previamente "licentia eius qui praeest portui in regno, qui dicitur magister portulanus". Desde su punto de vista, la concusión es inferida con absoluta discrecionalidad por el responsable del puerto, y se aplica a los que atracan en el mismo, aunque no están legitimados para hacer extorsiones, puesto que los

Chez C. Lamort, 1810, reimp. Aalen, Scientia Verlag, 1979, p. 412, interpreta el término latino "concussio" como périda.

133 BARTOLO DA SASSOFERRATO, In duodecim libros Codicis commentaria, Basileae 1562, p. 963, comentando la lex unica del C. Iust. 12, 45, de littorum et itinerum custodia: "In textu naucleri deponant. Notat hanc legem pro portantibus frumentum et aliud blandum, quando timent accusari de concussione, ut semper vadant coram officiali communis, et notificent ei ad quem locum portare velint. Nam hoc facto non timebunt de aliqua censione, quae contra eos fieri possit".

134 LUCA DE PENNA, In tres posteriores libros Codicis Iustiniani, Lugduni, apud Ioannam Iacobi Iuntae filiae, 1582, p. 903.

135 "Vim, id est, violentiam. Naucleros: nauclerus est dominus navis appellatus: quia eius navis sit forte secundum Isidorum Etymologiarum 19 cap. 1. Concussiones: quid sit concussio, C. 23 q. 1 caput et paratus in fine. Quae vero sit poena concussionis: respondeo, quadrupli". 
navíos debían pagar las tasas que legalmente se deben, pero ello no les daba derecho a percibir ingresos ilegalmente, como ladrones. Los naucleri tenían que declarar, antes de salir del puerto, que no se dirigían a los pueblos bárbaros, ni tampoco a los judíos, por interpretación analógica, siendo suficiente que expusieran el itinerario bajo juramento.

El mismo comentarista napolitano del siglo XIV136, al comentar esta norma de C. Iust. 12, 44, 1, recuerda que los naucleri o dueños de las naves, dedicadas a transportar productos para la annona, debían estar libres de cualquier violencia por parte de los funcionarios del Imperio, por lo cual no se les podía hacer ninguna extorsión, ni causar otro daño, o poner algún inconveniente, lo cual era compatible con el deber de los responsables administrativos del territorio para asegurarles una completa seguridad en el viaje, tanto de ida como de regreso, porque los que procedieran contraviniendo estos mandatos, sufrirían la sanción de diez libras de oro.

La interpretación facilitada por Cuyacio ${ }^{137}$, al tratar del contenido de esta norma justinianea, deja patente dos aspectos del precepto: la existencia de los custodes litorum, para evitar que las mercancías ilícitas, enumerando el vino, el aceite, la sal muera, es decir, garo y oxygaro (sal muera mezclada con vinagre), armas,

\footnotetext{
136 LUCA DE PENNA, In tres posteriores libros Codicis Iustiniani..., op. cit., p. 362. 137 CUYACIO, Jacques, Ad librum XII Codicis Justiniani commentarii, tit. XLIV, en Operum, t. II, Neapoli, typ. Moriana, apud V. Pauria, 1758, col. 979: C. Iust. 11, 44, 1. Custodiantur litora et portus ne merces illicitae ad hostes transferantur, veluti vinum, oleum, liquamen, id est, garum vel oxygarum, arma, ferrum, cotes, sales. Additur ne naves professae ullam concussionem sustineant. Curam littorum committere dicitur Comes sacrarum largitionum in formulis Cassiodori, et inde curiosi littorum in Novela Theodosii in trib. fisci.
} 
hierro, piedras y sal, lleguen a manos de los bárbaros, desde los puertos o el litoral, a través del contrabando, y la libertad de navegación, bajo supervisión última del Comes sacrarum largitionum, evitando, con la declaración del viaje marítimo del lugar de destino, por parte del responsable de la nave, el que pudiera sufrir cualquier extorsión.

Andrea de Barulo ${ }^{138}$, reitera que con esta disposición se prohíbe el transporte de mercancías a naciones bárbaras, prohibiendo la exportación de determinados productos, así como los viajes marítimos a lugares que no estaban permitidos, ni el comercio con mercancías prohibidas, sin que los naucleri incurran en delito, ni puedan ser objeto de concusión, siempre que declaren explícitamente el destino.

Novario, por su parte, comentando el contenido de algunas constituciones recogidas en los últimos libros del Código de Justiniano ${ }^{139}$, destaca que compete exclusivamente al Emperador el "derecho" de poder transportar mercancías, con cualquier tipo de medios de los particulares, incluso de naves, de un lugar a otro, bien sea para construirlas, o para atender al aprovisionamiento de la annona, siempre a cambio de un justo precio, lo cual está permitido incluso a una ciudad o comunidad que los necesite.

\footnotetext{
138 BARULO, Andrea de, Commentaria super tribus postremis libris Codicis, Venetiis, apud Sessas, 1601, p. 320..

139 NOVARIO, Giovanni Antonio, Scholia, seu commentaria ad aliquas trium librorum posteriorum Codicis leges ac rubricas, Neapoli, ex regia typ. Aegidij Longhi, sumpt. F. Balsami, 1631, pp. 192-193.
} 
Como indicaba Vismara ${ }^{140}$, en el imperio bizantino, las relaciones comerciales con los bárbaros, es decir, el comercio exterior con los países no sujetos al imperio, continuaron a estar reguladas por el conjunto de normas restrictivas del Bajo Imperio, que Justiniano había hecho propias, confirmando las disposiciones adoptadas por sus predecesores. En los Basílicos se encuentran las prohibiciones de exportar a los bárbaros vino, aceite y jugo de pescado en salmuera: B. $19,1,83,1=$ B. $10,1,86=$ C. 4,41 , 1: también repite la prohibición, para el hierro y las armas: Bas. 19, 1, 84 = C. Iust. 4, 41, 2, así como las piedras para amolar, sal y trigo: B. 56, 1, 10 = D. 39, 4, 11, sin olvidar los tejidos de púrpura: B. 19, 1, 80.

Sobre este argumento, retorna León el Filósofo, en la Novela 63, aboliendo la pena de muerte para los contraventores de la prohibición de exportar dichas mercancías, sustituyéndola, según la hipótesis, con penas pecuniarias, o corporales, e incluso con la esclavitud. Esta constitución bizantina, terminológicamente, ya no habla de barbari sino de hostes, apartándose de la legislación imperial posclásica romana, aunque en plena consonancia con la jurisprudencia clásica: D. 39, 4, 11 y D. 48. 4, 4, si bien en el contenido reitera la prohibición de exportar determinadas mercancías frente a todos los barbari, y no restrictivamente, como sanción contra el contrabando de guerra.

La disciplina romano-bizantina de las relaciones comerciales con los bárbaros, fundada en la prohibición de exportar determinadas mercancías incluso en tiempo de paz, constituye el punto de partida

140 VISMARA, Giulio, Limitazioni al comercio internazionale nell'Impero romano e nella comunitá cristiana medioevale, en Scritti in onore di Contardo Ferrini, pubblicati in occasione della sua beatificazione, vol. I, Milano, Vita e Pensiero, 1947, p. 450-452. 
de la legislación eclesiástica medieval, que regula las relaciones comerciales con los infieles. La principal innovación de la Iglesia, en esta materia, consiste en que el sujeto, en las relaciones con la cual se imponen ciertas limitaciones para la actividad comercial, viene calificado no por su falta de pertenencia al imperio (bárbaro), sino por su posición religiosa, por su participación o no en la comunidad de fieles. De este modo, se prohíbe exportar mercancías no solamente a los infieles paganos ${ }^{141}$, sino también a los herejes y a los excomulgados, los cuales, aunque participan de la civilización cristiana, se encuentran temporalmente fuera de la Iglesia, cuyo enemigo lo es al mismo tiempo de la Respublica christiana, por lo cual las prohibiciones de comerciar son una medida defensiva, conjuntamente adoptada por la comunidad de los fieles y la organización internacional cristiana.

Se prohíbe comerciar concretamente con los sarracenos ${ }^{142}$, respecto de los cuales y su comercio los Papas y el resto de poderes seculares de los reinos cristianos adoptan muchas medidas, no siempre eficaces. El primer elenco de mercancías excluidas del comercio con los sarracenos, contenido en una norma canónica, de aplicación para todos los miembros de la comunidad cristiana, viene en un canon del Concilio Lateranense del año 1179, de Alejandro III ${ }^{143}$. En el mismo se dispone que los cristianos no pueden transferir a los sarracenos: arma, ferrum et lignamina galearum, ni tampoco

\footnotetext{
141 Bárbaro equivale, en algunas fuentes, a pagano.

142 VISMARA, Giulio, Limitazioni al comercio internazionale nell'Impero romano e nella comunitá cristiana medioevale..., op. cit., pp. 453-462.

143 X 5. 6. 6. Cf. Friedberg, Aemilius, Corpus Iuris Canonici, vol. II. Decretalium collectiones, $2^{\mathrm{a}}$ ed., Graz 1959, col. 773.
} 
mandar o pilotar sus naves: nec in galeis et piraticis saracenorum navibus regimen curam gubernationis exerceant ${ }^{144}$.

En los siglos XII y XIII la regla general fue la libertad de comercio, y los pontífices intervinieron reiteradamente ante los poderes seculares para que fueran respetadas y observada la protección de los comerciantes, que se asentaban en los territorios de su soberanía, para que ejercitaran libremente el comercio. En consecuencia, pidieron la liberación de comerciantes retenidos injustamente como prisioneros, y la restitución de sus mercancías, entre otras medidas.

La doctrina mercantil de la Edad Moderna, siguiendo al Derecho romano, defendió la libre navegación por los mares y su utilización para el comercio, como vemos en Roderico Zuario ${ }^{145}$, quien pone de relieve que defender el uso del mar, (en exclusiva por parte de una población), es contra ius naturale, "quod maris usus communis est omnium", de modo que no cabe hablar de prescripción en este ámbito. Considerando que el bien es común a todos los hombres, y su uso de libre aprovechamiento de cada ciudadano, al emperador romano solamente le correspondió adoptar disposiciones "circa protectionem et iurisdictionem... nam mare et litora maris communia esse omnium iure naturali... litora, quod sunt omnia communia quantum ad usum et dominium sunt tamen populi romani quoad protectionem. Hinc Baldus ait, quod proprietas maris est nullius usus, quoad iurisdictionem est Caesaris".

\footnotetext{
144 Los elencos de mercancías prohibidas se reiteraron posteriormente. Cf. VISMARA, Giulio, Limitazioni al comercio internazionale nell'Impero romano e nella comunitá cristiana medioevale..., op. cit., p. 463.

${ }^{145}$ De mercatura decisiones, et tractatus varii, et de rebus ad eam pertinentibus. In quibus omnium authorum, praecipue Benvenuti Stracchae, Lugduni, sumpt. Claudij Landry, 1621, pp. 547-550: ZUARIO, Roderico, Consilia duo de usu maris, et navibus transvehendis, Consilium I. De usu maris.
} 
El régimen jurídico de los puertos y uso del mar heredado de Roma, es el que asumen las Partidas de Alfonso X, a mediados del siglo XII, recogiendo en Part. 3, 86, 3, lo relativo a rentas e impuestos que se deben al rey como derechos regios, mientras en otras leyes del mismo cuerpo legal se dispone: "portus nec aqua maris non nisi quoad protectionem et iurisdictionem", del poder real, tal como aparece en Partidas 3, 38, 10 y $12^{146}$.

Por otra parte, la recepción del Derecho romano, y su aplicación al comercio prohibido con los sarracenos, es objeto de reflexión intelectual por parte de los creadores del Derecho mercantil moderno, como vemos en Benvenuto Stracca ${ }^{147}$, para quien "mercatoribus christianis prohibitum esse commercium cum Saracenis et hostibus populi et imperii Romani tempore belli, non solum in mercibus prohibitis, verum in omnibus mercimonijs. Non enim licet deferre, et exportare, seu exportari facere ad huiusmodi gentes belli tempore merces aliquas. Quinimo belli tempore merces prohibitas etiam redimendorum captivorum gratia deferre non licet", conforme a X 5.6.11, aunque en este capítulo se permite llevar los productos para redimir cautivos, siempre que los

146 Es la doctrina imperante en Europa durante la Edad Moderna: cf. ARANA Y ANDRACA, Francisco, Repetitio ad textum in lege Omnibus fabricis $1 \mathrm{C}$. de fabricensibus, libro 11 titulo 9, en Commentaria ad sex selectiores Caesarum leges, quae in postremis duobus voluminis libris continentur, Matriti, ex typ. Iuliani de Paredes, 1688, pp. 40-71: es un derecho regio y la provisión de armamento necesaria a la República.

147 STRACCHA, Benvenuto, Tractatus de mercatura seu mercatore... accessit nunc primum eiusdem auctoris quotidianus de Adiecto Tractatus, in quo etiam dotium stipulationes usitatae, et quaestiones quotidianae quidem plene explicantur. Ex quibus tractatus de Mercatura perfectus redditur. Huc accessit perelegans Tractatus de mercatorum contractibus Ioannis Nider. Alius postea tractatus de Constituto, Baldi de Ubaldi... Postremo Roderici Suarii, Consilia duo, in quibus tractatur de usu maris et navibus transvehendis, Coloniae Agrippinae, apud Ioannem Gymnicum, sub Monocerote, 1576, pp. 78-80. Cf. STRACCHA, Benvenuto, Tractatus de mercatura seu mercatore, p. 357. 
sarracenos no obtengan "commodum aut subsidium". Por lo cual, “cum gentibus huiusmodi belli tempore commercium habere, et sibi subsidium seu consilium impendere prohibemus, et poena contra facientibus imminet, praeterea excommunicationis.

Stracca destaca que a nadie se le puede prohibir navegar en el mar, conforme a D. 43, 8, 2, 9 de Ulpiano, e Inst. Iust. 2, 1, 1, añadiendo el jurista italiano148: "intelligo istud interdictum ut quis a privato navigare impediri non possit, sed ab eo qui habet iura regalia in illo territorio, potest prohiberi". Por otra parte, la regulación legal aplicable, incluyendo el Ius Commune, especialmente la normativa romana de la Compilación justinianea, que en este campo es importante por las constituciones imperiales referidas en el Código, implica que ${ }^{149}$ "ablata est omnibus facultas comparandi serici a barbaris, excepto comite commerciorum. Frumentum etiam publici canonis in littoribus distrahi et emi capitali poena prohibitum est. Arma quoque privatis non licet facere, vendere, vel emere, vel transferre, solum enim fieri et vendi a privatis cultellos minores permissum est", y en consecuencia: "Admonendi etiam sumus ad barbaros, saracenos, hostesque Romani Imperij quascdam res, nec quidem mercaturae causa transferre prohibitum esse: ut ecce vinum, oleu, et alia liquamina ad huiusmodi gentes negotiationis, seu commercii etiam causa deferre vetamur, de acuerdo con C. Iust. 4, 41, 1. Idem iuris esse in aridis, conforme a D. 39, 4, ubi expressum est in frumento... Item Romani Imperij

\footnotetext{
148 STRACCHA, Benvenuto, Tractatus de mercatura seu mercatore... accessit nunc primum eiusdem auctoris quotidianus de Adiecto Tractatus, in quo etiam dotium stipulationes usitatae, et quaestiones quotidianae quidem plene explicantur..., op. cit., p. 323.

149 STRACCHA, Benvenuto, Tractatus de mercatura seu mercatore... accessit nunc primum eiusdem auctoris quotidianus de Adiecto Tractatus, in quo etiam dotium stipulationes usitatae, et quaestiones quotidianae quidem plene explicantur..., op. cit., pp. 131-134.
} 
hostibus sub quovis colore, loricas arcus, sagittas, spadas, gladius, tela, ferrum factum, vel infectum, vel alterius generis arma venundari et distrahi prohibitum est. Perniciosum namque Romano Imperio, et proditioni proximum est, barbaros, quos indigere convenit telis, eos, ut validiores reddantur, instruere": C. Iust. 4, 41, 2150 . En ese período se ampliaron los productos que no podían exportarse a los enemigos, entre los cuales se cita a los asturcones asturianos.

Zuario aporta un dictamen emitido con ocasión del conflicto marítimo surgido en el Mediterráneo ${ }^{151}$, durante el siglo XVI, entre unos comerciantes genoveses y otros vizcaínos, con ocasión del cargamento que hicieron los primeros, en su "nao", de paños y otras mercancías lícitas, por valor de diez mis ducados, mientras algunos mercaderes vizcaínos, por la fuerza, les tomaron el barco con su mercancía, y se la robaron "sub colore quod ducebantur in terram Saracenorum".

Argumenta Rodrigo Zuario, en defensa de los genoveses, que a pesar de la imputación de los vizcaínos, de que los genoveses llevaban armas y otras mercancías ilícitas a territorio de los sarracenos, que prueban mediante testigos, quienes declararon que llevaban dichas mercancías a Orán, los mercaderes de Génova

150 Finalmente, Stracca insiste en la prohibición de exportar piedra de afilar hierro, indispensable para los enemigos, al igual que el hierro ya preparado, el trigo y la sal, cuya contravención tiene pena capital, a tenor de D. 39, 4, 11, y añade en su elenco algunos términos, para referirse al armamento utilizado en su tiempo, así como otros productos no citados en las fuentes romanas y a los que se extiende por analogía, como son la plata, los asturcones asturianos, etc.

151 De mercatura decisiones, et tractatus varii, et de rebus ad eam pertinentibus..., ZUARIO, Roderico, pp. 550-552: Consilium II. De navibus transvehendis et mercibus exportandis. 
realmente iban a Cádiz, y los vizcaínos los acosaron hacia el estrecho, lo que les obligó a huir en otra dirección.

Dejando al margen la validez de sus testimonios, posibles sobornos y falsedad, Zuario reconoce que en la deposición se afirma que llevaban azogue, estaño y algunas botas de vino, pero las leyes solamente imponen la pena capital, si se lleva a los sarracenos armas, hierro y lignamina galearum o maderas para hacer barcos, conforme a C. Iust. 4, 41, 2, X 5. 6. 6, de Alejandro III y X 5. 6. 17 de Inocencio III, a propósito de los judíos, en cuyas últimas disposiciones solamente se dispone la caída en esclavitud y la pérdida de los bienes, si se incurre en los supuestos que contemplan, siguiendo al jurisconsulto Paulo, en D. 39, 4, 11, sin que sea un obstáculo el precepto de C. Iust. 4, 41, 1, de Valentiniano, Valente y Graciano, prohibiendo la exportación a los bárbaros de vino, aceite y sal muera, de modo similar a C. Iust. 4, 63, 4, en la que se prohíbe todo comercio con bárbaros, excepto las ferias de ciertas poblaciones y acompañantes de los embajadores. Lo mismo, a propósito de los judíos, se prescribe en X 5. 6. 11-12, cuyos preceptos no son de aplicación en este caso, porque tratan de enemigos, que solamente existen "quando inter Christianos et eos est Guerra: quia cum sint hostes, omne commercium censetur prohibitum: ita probatur aperte in dictis legibus, quia Barbari erant hostes populi Romani. Sic etiam dicit glosa", Innocencio III y el Abad Panormitano, comentando X 5. 6. 12, que manifiestan "tempore guerrae omne commercium est prohibitum, et omnes merces sunt prohibitae portari ad hostes: si tamen non sit guerra, tunc non intelligitur merces prohibita, et non incidit in poenam portans quascunque merces ad Saracenos, nisi esset aliqua de mercibus contentis in dicto capite. Ita quorundam scilicet arma, et 
ferrum et lignamina galearum: cum illa etiam tempore pacis sint prohibita", concordando expresamente, con este criterio, Partidas 5, 5, 22: “arma de fuste ni de hierro no deven vender los Christianos a los Moros, ni a los enemigos de nuestra fe", y añade "otrosi defendemos, que ninguno lleve a su tierra trigo, ni cebada ni vino ni óleo, mientras guerraren con", de lo que se deduce que las armas indistintamente están prohibidas, así como otros productos y vituallas en tiempo de guerra.

A la luz del razonamiento, Zuario entiende que es notorio que en ese momento el comercio no estaba prohibido "in Barbaria”, territorio moro, y menos, “Cadiz según la costumbre, que está provada, y según la provisión de contadores, que concuerda con la dicha distinción: y aun ay muy gran presumpcion de no llevar las dichas armas assi esta provado por los mismos que cargaron la dicha nao, mayormente que las dichas naos se registraron con todas las mercaderias, que en ellas yvan, y se registraron delante el Almirante, y su teniente, y con aquella solenidad yvan seguras", como indica paladinamente C. Iust. 12, 44 (45) 1, por lo que efectuados los requisitos exigidos, "nulla contra eos postea indignatio seu concussio procedat", a tenor de C. Iust. 11, 2, 1, de Constancio y Juliano.

Por otro lado, afirma Zuario que "Ay testigos que estuvieron presentes quando las partes contrarias repartieron las dichas mercaderías que assi robaron a los genoveses, las vieron descoger, dizen que en ellas no avia armas, ni cosas vedadas", recordando el comentario de Bártolo a C. Iust. 12, 44 (45) 1, cuya norma, para los que transportan trigo y otras mercancías a otro lugar, previene a los comerciantes que vayan ante el oficial de la municipalidad, 
notificándole el destino, ejecutado lo cual no pueden recibir mal alguno contra ellos, extorsión o pena.

El defensor de los genovesos, incluso, argumenta del supuesto según el cual llevar armas o vino en la nave está justificadco, porque “y si se prueba aver llevado armas o vino no les preiudica: porque aquello podría ser algunas armas para defensa de la nao y algun vino para su mantenimiento...", admitiendo que de los autos judiciales "se prueba que esas herraduras o hierros de lanças las llevava ençerradas en un arca un moro del adelantado que allí yva", de modo que si en la nave iban productos lícitos e ilícitos, los bienes lícitos no se pueden perder ni confiscar a causa de las mercancías ilícitas, salvo que se pruebe que el que transportaba las lícitas era consciente y partícipe del delito.

La última parte de su análisis se refiere a la titularidad de las mercancías ilícitas, transportadas en la nave, cuya solución, mediante conjeturas, depende de la calidad del objeto y de la persona a quien perteneciese, siguiendo a Baldo degli Ubaldi. En el supuesto concreto, las mercancías fueron capturadas "in itinere, non in loco saracenorum: quia si aliquis portaret ferrum in Barbariam, et reperitur in itinere, non punitur poena statuta contra portantes arma ad hostes", ya que no se habría consumado el delito. Los vizcaínos, una vez que cogieron las mercancías del barco genovés, estaban obligados a manifestarlo ante el juez u otro oficial público, para no incurrir en fraude, y ante dicha autoridad estaban obligados a declarar qué cosas llevaban los genoveses, porque de otro modo era posible que robasen el barco y sus mercancías sin legitimidad alguna, amparándose en la suposición de llevar cosas ilícitas que fueron encontradas en la nave, para lo que 
se podrían servir de partícipes en el delito, como "prueba la ley de Enrique IV, dada en Toledo el año 1472, petición 27, que expresamente dispone, en el caso de capturas de cosas prohibidas que se exportan del reino, el que hace la captura "debet praesentare infra viginti quatuor horas iudici loci magis propinqui, ut fraus cesset... quia poena apposita contra portantes arma ad hostes est poena capitis et bona fisco applicantur", conforme a C. Iust. 4, 41, 2; C. Iust. 4, 63, 4; D. 39, 4, 11 de Paulo, y Partidas 5, 5, 22, en el que se preceptúa que los bienes pertenecen al fisco, mientras la persona queda a merced del Rey. Por Derecho canónico, tanto los bienes como la persona quedan en poder del que lo captura, según los capítulos más arriba citados, por lo cual en este supuesto los bienes no podrán pertenecer a los vizcaínos, sino al fisco, a cuyo favor se pronunciará la sentencia.

En la doctrina española del período, sirve de referencia el asturiano Hevia Bolaños, quien en el segundo tomo de su Curia Filípica152, empieza por admitir que el uso del mar, por Derecho natural, es común de todos los del mundo, de modo que cada uno puede usar de ello, pescando, navegando y haciendo todo lo demás que le pareciere ${ }^{153}$, por lo cual si alguien se lo prohíbe, conforme al Derecho romano, dispone de la acción por injurias. No obstante, reconoce en el Príncipe la potestad de jurisdicción para su gobierno, y la capacidad de protección para su defensa, tanto frente a los corsarios que le infestaren, como en su distrito, percibiendo derechos

152 HEVIA BOLAÑOS, Juan de, Curia Filípica. Primero y segundo tomo. El primero dividido en cinco partes, donde se trata breve y compendiosamente de los Juicios... el segundo tomo, en tres libros distribuido, donde se trata de la mercancía y contratación de tierra, y mar, Madrid, imp. de Manuel Fernández, 1733, pp. 174-210.

153 HEVIA BOLAÑOS, Juan de, Curia Filípica..., t. II, op. cit., pp. 175-177. 
reales de las cosas que entran y salen de la mar. Esta misma libertad de utilización se aplica a la ribera del mar, además de que el uso del puerto es también común a todo el mundo ${ }^{154}$.

En el comercio naval155, Hevia Bolaños recuerda que, siguiendo al precepto de Teodosio II, recogido por Justiniano, antes de iniciar el viaje, el maestre de la nave ha de declarar "el puerto donde va, y ha de traer testimonio o información de cómo fue a el, y allí descargó las cargas; y no lo haciendo, o pareciendo después que fue a otro puerto, o parte diferente, la nave es perdida o confiscada, y las mercaderías son decomisadas". Arribado al destino, y antes de que salte ninguno a tierra, el maestre ha de entregar a los oficiales reales las cartas y registro que llevare, conforme a las ordenanzas.

El asturiano aborda el ámbito de las cosas vedades o prohibidas para ser sacadas de un reino a otro ${ }^{156}$, aunque rige el principio de libertad de comerciar con todo tipo de producto, a no ser que afecte a la mercancía alguna prohibición, que no podrá quebrantarse "sin expresa y especial licencia regia", conforme a Recop. 9, 19, 28. En el siglo XVII sigue vigente la libre exportación de mercaderías, aunque uno de los reinos no sea de cristianos, con tal que no sean enemigos de la fe, con quien se tenga guerra. Mientras durase la misma, no se podrán exportar ni importar mercaderías, ni otras cosas, de un

154 Trata del maestre de la nave, elegido por el dueño, y a cuyo cargo, orden y mandato está toda la nave, sus cosas y marineros, correspondiéndole el cuidado de la misma, independientemente de que sea dueño o arrendador de la nave, $o$ extraño, libre o siervo, o menor de edad, a diferencia del piloto que es el que gobierna la nave y debe tener ciencia para ese oficio, siendo elegido por el maestre. HEVIA BOLAÑOS, Juan de, Curia Filípica..., t. II, op. cit., p. 189.

155 HEVIA BOLAÑOS, Juan de, Curia Filípica..., t. II, op. cit., pp. 222-224.

156 HEVIA BOLAÑOS, Juan de, Curia Filípica..., t. II, op. cit., pp. 202-206. 
pueblo a otro, aunque no estén prohibidas, y los contendientes sean cristianos, o uno de ellos no lo sea ${ }^{157}$.

\section{CONCLUSIONES}

Examinando el contenido de la constitución del Teodosiano C. Th. 7, 16, 3, el primer aspecto que emerge y merece ser destacado es que las naves no pueden ser retenidas en los puertos del Imperio o sufrir hostigamientos, es decir, extorsiones o detenciones de las naves que afecten a su actividad marítima, si el nauclerus o el mercator manifiestan al defensor locorum, en presencia del 'protector seu ducianus', el destino del viaje marítimo, y lógicamente el lugar de desembarco de las mercancías.

El documento de la declaración viene conservado en los "acta publica", a través de una copia, mientras el original de dicha

157 Sobre la doctrina del siglo XVIII, es significativa la de PEREZ, Antonio, Praelectiones in duodecim libros Codicis Iustiniani, t. I, Venetiis, apud Joannem Baptistam Constantini, 1783, p. 343: Comenta C. Iust. 12, 45, 1, de litorum et itinerum custodia, recordando la disposición de Justiniano, "littora et itinera custodienda, ne illicitae merces ad hostes defferantur", y enumerando los productos que estaban prohibidos en Derecho justinianeo, ley 1 C. quae res exportari nequit. Siguiendo al Derecho posclásico-justinianeo, muestra cómo sacar productos de un reino exige hacer la declaración ante la autoridad pública, señalando el lugar al que se llevan, porque en otro caso los contraventores sufren una penalidad, se confisca la nave para el fisco, salvo que ausente el dueño, y no siendo consciente del delito, se realice por el magister navis, o por el gubernator, o por el nauta, que vienen castigados con la pena capital y la confiscación de las mercancías, remitiendo a ley $11 \& 2 \mathrm{ff}$. de publicanis et vectigalibus, y a Bobadilla ley 3 Politica para corregidores y señores de vasallos, c. 5. Las mercancías deben ser inspeccionadas y anotadas por razón de las tasas que se abonan al erario, salvo en alimentos de primera necesidad, y así también evitar que salgan productos indispensables en el reino, con ejemplo relativo a España y productos relevantes. 
manifestación, denominada 'authenticus' se guardaba por el nauclerus o el mercator durante el viaje.

En caso de transbordo de la mercancías de una nave a otra, en cualquier puerto del Impero, el nauclerus debía tener documentación de la descarga de la mercancía, mientras el mercator atestiguaría la licitud del transporte.

El jurisconsulto Paulo, en D. 39, 4, 11pr. ${ }^{158}$, al señalar que no es lícito vender a los enemigos, sin el riesgo de perder la vida, la piedra necesaria para afilar el hierro, del mismo modo que tampoco se les podía vender el hierro, el trigo, ni la sal. Por lo que respecta a la sal, y sus sustitutivos, como el jugo del pescado conservado en salmuera, al prohibir su exportación, se trata de alejar a los bárbaros de los confines del Imperio, privándoles de un elemento necesario para la conservación de la vida humana.

El mismo planteamiento se observa en Valentiniano, Valente y Graciano, a principios del último tercio del siglo IV $^{159}$, al disponer que nadie tuviera facultad para transportar a los pueblos extranjeros vino, aceite $u$ otros líquidos, castigando severamente a los traficantes que utilizan el oro con estos pueblos extranjeros y al juez, que habiendo descubierto la conducta ilícita, no reclama el oro, y a los que enseñaran el arte sino que se comporta como cómplice del delito160, mientras el año 419, Teodosio y Honorio impone la pena capital a los que enseñaran el arte de construir naves a las poblaciones bárbaras, que eran todavía inexpertas en ese oficio: C. Th. 9, 20, $24=9,17,25$.

158 Paulus libro $V$ sentent. Cotem ferro subigendo necessariam hostibus quoque venundari, ut ferrum, et frumentum, et sales, non sine periculo capitis licet.

159 C. Iust. 4, 41, 1. Impp. Valentin. Valente y Graciano (370-375).

160 y C. Iust. 4, 63, 2. Impp. Valentinianus et Valens et Gratianus. 
Al año siguiente, los mismos emperadores ${ }^{161}$, renovaron la prohibición de exportar merces illicitae, estableciendo un sistema de vigilancia y control, que debía efectuarse en los puertos de embarque y en el litoral: C. Th. 7, 16, 3 = C. Iust. 12, 44 (45) 1162. No obstante, la normativa más radical vino de Marciano, a mediados del siglo V: C. Iust. $4,41,2^{163}$.

Como recuerda Acursio en la glosa ${ }^{164}$, la prohibición de exportar a los extranjeros unas mercancías que se juzgaban ilícitas, afectaba especialmente a los comestibles y a las armas, de modo que quienes traficaban contraviniendo lo dispuesto legalmente sufrían la pena capital con pérdida de todo su patrimonio.

Después de esta constitución no parece que se hubieran promulgado nuevas disposiciones imperiales en materia de las relaciones comerciales con los bárbaros, porque el conjunto de prohibiciones era tan estricto, que difícilmente podría adicionarse o superarse con alguna otra. La cuestión se trasladaba entonces al terreno práctico, en la lucha contra la avidez de lucro de los comerciantes, y la corrupción de los funcionarios imperiales.

\section{BIBLIOGRAFÍA}

161 VISMARA, Giulio, Limitazioni al comercio internazionale..., op. cit., p. 449-450. 162 Cf. GAURIER, Dominique, Le Droit maritime romain, Rennes, Presses Universitaires, 2004, pp. 135-140, especialmente pp. 140-142, con la remisión a las mercancías prohibidas y a la custodia de los litorales del Mediterráneo, justificando la supresión en Justiniano, por la falta de conflictividad, y control absoluto del mismo por el poder político del Imperio.

163 C. Iust. 4, 41, 2,

164 Corpus Glossatorum Iuris Civilis. Accursii, glossa in Codicem, Venecia 1488, vol. XI, Glossa in Volumem, reimpr. facs. Augustae Taurinorum, ex officina Erasmiana, 1969, p. 428. 
AA. VV., De mercatura decisiones, et tractatus varii, et de rebus ad eam pertinentibus. In quibus omnium authorum, praecipue Benvenuti Stracchae, Lugduni, sumpt. Claudij Landry, 1621: ZUARIO, Roderico, Consilia duo de usu maris, et navibus transvehendis, Consilium I. De usu maris. Consilium II. De navibus transvehendis et mercibus exportandis. AA. VV., The Theodosiam Code. Studies in the Imperial Law of late Antiquity, ed. By J. Harries et Ian Wood, London, Duckworth, 1993. ALBERICUS DI ROSATE, Dictionarium iuris tan civilis quam canonici, Venetiis, apud Guerreos, 1573, reimpr. anast. Roma, La Bottega d'Erasmo, 1971.

ALCIATO, Andreas, Opera omnia, t. I. De verborum et regum significatione libris quatuor, Basileae, ex off. Isingriniana, 1558, reimpr. Frankfurt am Main, Vico Verlag, 2004.

AMMIEN MARCELLIN, Histoire, tome V (livres XXVI-XXVIII). Teste établi, trad. et ann. par Marie-A. Marié, París, Les Belles Lettres, 1984. ARANA Y ANDRACA, Francisco, Repetitio ad textum in lege Omnibus fabricis 1 C. de fabricensibus, libro 11 titulo 9, en Commentaria ad sex selectiores Caesarum leges, quae in postremis duobus voluminis libris continentur, Matriti, ex typ. Iuliani de Paredes, 1688.

ARCHI, Giangualberto, Teodosio II e la sua codificazione, Napoli, Jovene, 1976.

BARTOLO DA SASSOFERRATO, In duodecim libros Codicis commentaria, Basileae, per Hieronimum Frebonium et Nicolaum Episcopium, 1562.

BARULO, Andrea de, Commentaria super tribus postremis libris Codicis, Venetiis, apud Sessas, 1601. 
BIGIAVI, Walter, Studi di storia del diritto commerciale romano, en Rivista del Diritto Commerciale, 1 (1930) 850 y ss.

BONFANTE, Pietro, Istituzioni di Diritto romano, $8^{\mathrm{a}}$ ed., Milano, Francesco Vallardi, 1925.

BRUNETTI, Antonio, Diritto marítimo privato italiano, vol. I, Torino, Unione Tipografica, 1929.

Codex Theodosianus, cum perpetuis commentariis Jacobi Gothofredi, praemittuntur chronologia accuratior, cum chronico historico et prolegomena, t. II, Lugduni, sumpt. Ioannis-A. Huguetan et Marci-A. Ravaud, 1665.

CODICIS THEODOSIANI LIBRI XVI... adiectae sunt suis locis Aniani V. S. interpretationes..., Parisiis, apud Sebastianum Nivellium, sub ciconiis, 1586.

COMA FORT, José María, Codex Theodosianus: historia de un texto, Madrid, Universidad Carlos III, 2014.

CONTE, Gian Biagio - PIANEZZOLA, Emilio - RANUCCI, Giuliano, Il dizionario della Lingua latina, Firenze, Le Monnier, 1994.

Corpus Glossatorum Iuris Civilis. Accursii, glossa in Codicem, Venecia 1488, vol. XI, Glossa in Volumem, reimpr. facs. Augustae Taurinorum, ex officina Erasmiana, 1969.

CUJAS, Jacques, Ad titulum LXI de vectigalibus et commissis, libro IV Codicis, en Operum, t. IX, Neapoli, typ. Moriana, apud V. Pauria, 1758. CUJAS, Jacques, Notae ad librum XXXIV Digestorum, tit. IX, en Operum, t. X, Neapoli, typ. Moriana, apud V. Pauria, 1758.

CUJAS, Jacques, Operum, t. II, Neapoli, typ. Moriana, apud V. Pauria, 1758. 
CUJAS, Jacques, Recitationes solemnes, ad titulum IX. De his quibus ut indignis, liber XXXIV Digestorum, en Operum, t. VII, Neapoli, typ. Moriana, apud V. Pauria, 1758.

CUQ, Edouard, Manuel des Institutions juridiques des Romains, París, Librairie Plon, 1917.

DAREMBERG, Charles -SAGLIO, Edm., Dictionnaire des Antiquités grecques et romaines, $D-S$, t. III-Deuxième partie y $t$. IV. Première pàrtie, París, Hachette, 1907, reimpr. fot, Graz, Akademische Druck - U. Verñagsanstalt, 1969.

DE DOMINICIS, Antonio, en Nuovo Digesto Italiano, vol. 8, Torino, Unione tipográfico-editrice, 1939, s. v. magister navis.

DE MARINI AVONZO, Francesca de, La politica legislativa di Valentiniano III e Teodosio II, 2ª ed., Torino, Giappichelli, 1975.

DE MARTINO, Francesco, Historia económica de la Roma antigua, trad. del ital. por E. Benítez, vol. I, Torrejón de Ardoz, Akal, 1985.

DE MIGUEL, Raimundo, Nuevo Diccionario latino-español etimológico, Madrid, Sáenz de Jubera, 1931.

DEMOUGEOT, Emilienne, De l'unité a à la división de l'Empire romain, 395-410. Essai sur le gouvernement impérial, París, A. Maisonneuve, 1951.

DEMOUGEOT, Emilienne, La formation de l'Europe et les invasions barbares, t. II. De l'avénement de Dioclétien au debut du VIe siècle, París, Aubier, 1979.

DI PAOLA, Lucietta, I curiosi in età tardoantica. Riflessioni in margine al titolo VI,29 del Teodosiano, en AA. VV., Le Code Théodosien. Diversité des approches et nouvelles perspectives. Études réunies par Sylvie Crogiez- 
Pétrequin et Pierre Jaillette. Atti del convegno tenuto a Parigi nel 2009, Rome, École Française de Rome, vol. 412, 2009, pp. 125 y ss.

DI PAOLA, Lucietta, Per la storia degli "occhi del re". I servizi ispettivi nella Tarda Antichità, Messina, Sc. A. M., 2005.

ELIO ESPARCIANO, Escritores de la Historia Augusta, trad. del latín por F. Navarro y Calvo, Madrid, Sucesores de Hernando, 1919.

ERNOUT, A. - MEILLET, A., Dictionnaire étymologique de la Langue Latine. Histoire des mots, $4^{\mathrm{a}}$ ed., $2^{\mathrm{a}}$ tir., augm. de corr. nouv., París, C. Klincksieck, 1967.

FALCHI, Giuseppino Ferruccio, Diritto penale romano, t. II. I singoli reati, Padova, Zannoni, 1932.

FERNÁNDEZ DE BUJÁN, Antonio, Derecho público romano, 22ª ed., Madrid, Civitas, 2019.

FRIEDBER, Aemilius, Corpus Iuris Canonici, vol. II. Decretalium collectiones, $2^{\text {a }}$ ed., Graz 1959.

GAUDEMET, Jean, La formation du droit séculier et du droit de l'Eglise aux IVe et Ve siècles, 2a ed., París, Sirey, 1979.

GAURIER, Dominique, Le Droit maritime romain, Rennes, Presses Universitaires, 2004.

GIUFFRÈ, Vincenzo, Iura e arma: Intorno al VII libro del Codice Teodosiano, Napoli, Jovene, 1979.

GODEFROY, Iacques, De imperio maris et de iure naufragii colligendi legeque Rhodia, ex Iure romano, en Opuscula varia; iuridica, politica, historica, critica, Genevae, sumpt. Ioannis Antonij et Samuelis de Tournes, 1654.

GODEFROY, Jacques, Manuale juris seu parva juris mysteria, ubi quatuor sequentia continentur Juris civilis romani... Florilegium 
sententiarum juris... ex Corpore Justinianeo desumptarum. IV. Series librorum et titulorum in Digestis et in Codice, $11^{\text {a }}$ ed., auct. et accur., Genevae, sumpt. Gabrielis de Tournes et fil., 1726.

GRADENWITZ, Otto, Heidelberger Index zum Theodosianus, mit Ergänzungsband. Hergestellt unter Leitung von..., Berlín, Weidmann 1970.

GUARINO, Antonio, Diritto privato romano, $4^{\mathrm{a}}$ ed. riv., Napoli, Jovene, 1970.

HEVIA BOLAÑOS, Juan de, Curia Filípica. Primero y segundo tomo. El primero dividido en cinco partes, donde se trata breve y compendiosamente de los Juicios... el segundo tomo, en tres libros distribuido, donde se trata de la mercancía y contratación de tierra, y mar, Madrid, imp. de Manuel Fernández, 1733.

HISTORIA AUGUSTA. Römische Herrschergestalten, t. I, von Hadrianus bis Alexander Severus, Zürich und München, Artemis, 1976.

HUVELIN, Paul, Estudes du Droit comercial romain (histoire externe Droit maritime, París, Sirey, 1929.

IGLESIAS, Juan, Derecho romano, 12ª ed., Barcelona, Ariel, 1999.

JONES, A. H. M., The Roman Economy. Studies in Ancient Economic and Administrative History, ed. por P. A. Brunt, Oxford, B. Blackwell, 1974. JONES, A. Hugo M. Il tardo impero romano, 284-602 d. C., t. I, trad. de E. Petretti, Milano, Il Saggiatore, 1973; t. II, 1974; t. III, 1981.

LES DOUZE LIVRES DU CODE DE L'EMPEREUR JUSTINIEN, de la seconde édition. Trad. en français par P.-A. Tissot..., t. IV, Metz, Chez C. Lamort, 1810, reimp. Aalen, Scientia Verlag, 1979.

LUCCA DA PENNA, In tres posteriores libros Codicis Iustiniani, Lugduni, apud Ioannam Iacobi Iuntae filiae, 1582. 
MACMULLEN, Ramsay, Le déclin de Roma et la corruption du pouvoir. Trad. de l'anglais par A. Spiquel et A. Rousselle, Paris, Les Belles Lettres, 1991.

MARQUARD, Johannes, Tractatus politico-juridicus De iure mercatorum et commerciorum singulari, Francofurti, imp. Thomae M. Götż̈, 1662. MATTHEWS, John F., Laying Down the Law. A study of the Theodosian Code, Yale, University Press, 2000.

MOMMSEN, Theodor, Derecho penal romano, Bogotá, Temis, 1976.

MOSCHETTI, Cesare Maria, Gubernare navem. Gubernare rem publicam. Contributo alla storia del diritto marittimo e del diritto pubblico romano, Milano, Griuffrè, 1966.

MOSCHETTI, Cesare Maria, Notae al libro de J. Rougé, Aspetti organizzativi dell'attività commerciale marittima nel bacino del Mediterraneo durante l'Impero romano, en SDHI 35 (1969) 388-410.

NACK, Emil - WÄGNER, Wilhem, Roma. El país y el pueblo de los antiguos romanos. Trad. por J. Godo Costa, $2^{\mathrm{a}}$ ed., Barcelona, Labor, 1966.

NOVARIO, Giovanni Antonio, Scholia, seu commentaria ad aliquas trium librorum posteriorum Codicis leges ac rubricas, Neapoli, ex regia typ. Aegidij Longhi, sumpt. F. Balsami, 1631.

PANERO GUTIÉRREZ, Ricardo, Derecho romano, Valencia, Tirant lo Blanch, 2004.

PAOLI, Ugo Enrico, en Nuovo Digesto Italiano, vol. 8, Torino, Unione tipográfico-editrice, 1939, s. v. naucleros.

PECK, Pierre, In omnes titulos ad rem nauticam pertinentes, HagaeComitis, ex off. Hildebrandi Iacobi, 1603. 
PEREZ, Antonio, Praelectiones in duodecim libros Codicis Iustiniani, t. I, Venetiis, apud Joannem Baptistam Constantini, 1783.

PHARR, Clyde, in collaboration with Theresa Sherrer Davidson and Mary Broum Pharr, with an introduction by C. Dickerman Williams, The Theodosiam Code and Novels and The Sirmondian Constitutions. A translation with commentary, glossary, and bibliography, Princeton, University press, 1952.

PIGANIOL, André, Historia de Roma, trad. del francés por R. Anaya, $3^{\mathrm{a}}$ ed., Buenos Aires, editorial universitaria, 1974.

PLATEA, Joannes de, Super tribus ultimis libris Iustiniani Codicis Commentaria: noviter castigata et emendata. Ornataque annotationibus atque additionibus marginalibus per magistrum Ioannem de Gradibus, Lugduni, Jacobus Myt, sumpt. Bart. Trot, 1516.

ROMANO, Santi, en Nuovo Digesto Italiano, vol. 4, Torino, Unione tipográfico-editrice, 1938, s. v. defensor civitatis.

ROUGÉ, Jean, Recherches sur l'organisation du commerce maritime en Méditerrenée sous l'Empire Romain, París, SEVPEN, 1966.

SANDIFORD, Roberto - PAPI SPANU, Luigi, Istituzioni di Diritto della navigazione, vol. I, rist., Roma, Ateneo, 1948.

SANDIFORD, Roberto, Il diritto marittimo dei romani. Conferenza letta il 6 aprile 1940 A-XVIII al Associazione Archeologica Romana, Roma, s. e., 1940.

SOLAZZI, Siro, Appunti di diritto romano marittimo, en Rivista del Diritto della navigazione, 1936, 113 y 268, y en Scritti di Diritto romano, vol. III, Napoli, Jovene, 1960.

STARR, Chester, Storia del mondo antico, trad. del inglés, $2^{\mathrm{a}}$ ed. riv. e agg., Roma, Editori Riuniti, 1977. 
STRACCHA, Benvenuto, Tractatus de mercatura seu mercatore... accessit nunc primum eiusdem auctoris quotidianus de Adiecto Tractatus, in quo etiam dotium stipulationes usitatae, et quaestiones quotidianae quidem plene explicantur. Ex quibus tractatus de Mercatura perfectus redditur. Huc accessit perelegans Tractatus de mercatorum contractibus Ioannis Nider. Alius postea tractatus de Constituto, Baldi de Ubaldi... Postremo Roderici Suarii, Consilia duo, in quibus tractatur de usu maris et navibus transvehendis, Coloniae Agrippinae, apud Ioannem Gymnicum, sub Monocerote, 1576.

TEDESCHI, Guido, Il diritto marítimo dei romani comparato al diritto marítimo italiano, Montefiascone, tip. Silvio Pellico, 1899.

VARELA GIL, Carlos, El estatuto jurídico del empleado público en Derecho romano, Madrid, Dykinson, 2007.

VISMARA, Giulio, Limitazioni al comercio internazionale nell'Impero romano e nella comunitá cristiana medioevale, en Scritti in onore di Contardo Ferrini, pubblicati in occasione della sua beatificazione, vol. I, Milano, Vita e Pensiero, 1947, pp. 443-470.

ZEILLER, Jacques, L'Empire romain et l'Eglise, París, E. de Boccard, 1928. 